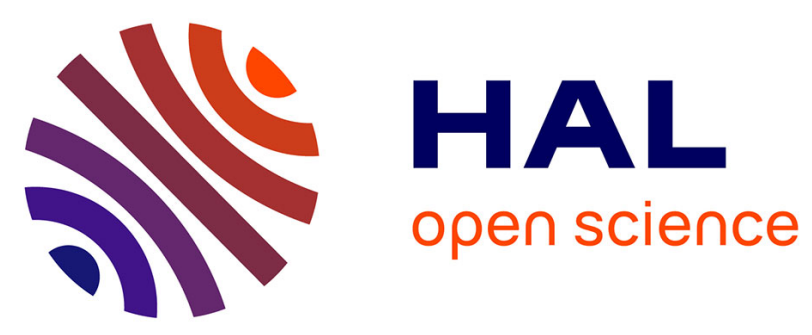

\title{
Moraine crest or slope: An analysis of the effects of boulder position on cosmogenic exposure age
}

Matt Tomkins, Jason Dortch, Philip Hughes, Jonny Huck, Raimon Pallàs, Ángel Rodés, James Allard, Andrew Stimson, Didier Bourlès, Vincent Rinterknecht, et al.

\section{To cite this version:}

Matt Tomkins, Jason Dortch, Philip Hughes, Jonny Huck, Raimon Pallàs, et al.. Moraine crest or slope: An analysis of the effects of boulder position on cosmogenic exposure age. Earth and Planetary Science Letters, 2021, 570, pp.117092. 10.1016/j.epsl.2021.117092 . hal-03436132

\section{HAL Id: hal-03436132 https://hal.science/hal-03436132}

Submitted on 22 Nov 2021

HAL is a multi-disciplinary open access archive for the deposit and dissemination of scientific research documents, whether they are published or not. The documents may come from teaching and research institutions in France or abroad, or from public or private research centers.
L'archive ouverte pluridisciplinaire HAL, est destinée au dépôt et à la diffusion de documents scientifiques de niveau recherche, publiés ou non, émanant des établissements d'enseignement et de recherche français ou étrangers, des laboratoires publics ou privés. 


\title{
Moraine crest or slope: An analysis of the effects of boulder position on cosmogenic exposure age
}

\author{
Matt D. Tomkins ${ }^{\mathrm{a}, \mathrm{b}, *}$, Jason M. Dortch ${ }^{\mathrm{c}}$, Philip D. Hughes ${ }^{\mathrm{a}, \mathrm{b}}$, Jonny J. Huck ${ }^{\mathrm{a}}$, \\ Raimon Pallàs ${ }^{\mathrm{d}}$, Ángel Rodés ${ }^{\mathrm{e}}$, James L. Allard ${ }^{\mathrm{a}, \mathrm{b}}$, Andrew G. Stimson ${ }^{\mathrm{a}}$, Didier Bourlès ${ }^{\mathrm{f}}$, \\ Vincent Rinterknecht ${ }^{\mathrm{f}}$, Vincent Jomelli ${ }^{\mathrm{f}}$, Laura Rodríguez-Rodríguez ${ }^{\mathrm{g}}$, Ramon Copons ${ }^{\mathrm{h}}$, \\ Iestyn D. Barr ${ }^{\mathrm{i}, \mathrm{b}}$, Christopher M. Darvill ${ }^{\mathrm{a}, \mathrm{b}}$, Thomas Bishop ${ }^{\mathrm{a}}$ \\ a Department of Geography, University of Manchester, Manchester, M13 9PL, UK \\ b Cryosphere Research at Manchester, Manchester, UK \\ c Kentucky Geological Survey, University of Kentucky, Lexington, USA \\ d Departament de Dinàmica de la Terra i de l'Oceà, Universitat de Barcelona, 08028 Barcelona, Spain \\ e Scottish Universities Environmental Research Centre, Rankine Avenue, East Kilbride G75 0QF, UK \\ f Aix-Marseille Univ., CNRS, IRD, INRA, Coll France, UM 34 CEREGE, Technopôle de l'Environnement Arbois-Méditerranée, BP80, 13545 Aix-en-Provence, France \\ ${ }^{g}$ Dpto. Ciencias de la Tierra y Física de la Materia Condensada, Universidad de Cantabria, Avenida de los Castros s/n, 39005 Santander, Spain \\ h Snow and Mountain Research Centre of Andorra (CENMA), Andorran Research Institute (IEA), Sant Julià de Lòria, Andorra \\ i Department of Natural Sciences, Manchester Metropolitan University, Manchester, UK
}

\section{A R T I C L E I N F O}

\section{Article history:}

Received 24 December 2020

Received in revised form 15 May 2021

Accepted 28 June 2021

Available online 19 July 2021

Editor: J.-P. Avouac

\section{Keywords:}

cosmogenic nuclides

moraine

geologic uncertainty

degradation

weathering

Schmidt hammer

\begin{abstract}
A B S T R A C T
Terrestrial cosmogenic nuclide dating of ice-marginal moraines can provide unique insights into Quaternary glacial history. However, pre- and post-depositional exposure histories of moraine boulders can introduce geologic uncertainty to numerical landform ages. To avoid geologic outliers, boulders are typically selected based on their depositional context and individual characteristics but while these criteria have good qualitative reasoning, many have not been tested quantitatively. Of these, boulder location is critical, as boulders located on moraine crests are prioritised, while those on moraine slopes are typically rejected. This study provides the first quantitative assessment of the relative utility of moraine crest and moraine slope sampling using new and published ${ }^{10} \mathrm{Be}$ and ${ }^{36} \mathrm{Cl}$ ages $(n=19)$ and Schmidt hammer sampling (SH; $n=635$ moraine boulders, $\sim 19,050$ SH $R$-values) in the northern and southern Pyrenees. These data show that for many of the studied moraines, the spatial distribution of "good" boulders is effectively random, with no consistent clustering on moraine crests, ice-proximal or -distal slopes. In turn, and in contrast to prior work, there is no clear penalty to either moraine crest or moraine slope sampling. Instead, we argue that landform stability exerts a greater influence on exposure age distributions than the characteristics of individual boulders. For the studied landforms, postdepositional stability is strongly influenced by sedimentology, with prolonged degradation of matrix-rich unconsolidated moraines while boulder-rich, matrix-poor moraines stabilised rapidly after deposition. While this pattern is unlikely to hold true in all settings, these data indicate that differences between landforms can be more significant than differences at the intra-landform scale. As ad hoc assessment of landform stability is extremely challenging based on geomorphological evidence alone, preliminary SH sampling, as utilised here, is a useful method to assess the temporal distribution of boulder exposure ages and to prioritise individual boulders for subsequent analysis.
\end{abstract}

\section{Introduction}

Ice-marginal moraines are classic features of glaciated mountain ranges and are prominent terrestrial records of glacial history

\footnotetext{
* Corresponding author.

E-mail address: matthew.tomkins@manchester.ac.uk (M.D. Tomkins).
}

(Hallet and Putkonen, 1994). By constraining the timing of moraine deposition, it is possible to reconstruct the growth and decay of glaciers and ice sheets through the Quaternary and the palaeoclimatic drivers of glacial cycles. Recent developments in terrestrial cosmogenic nuclide (TCN) dating have transformed our understanding of Quaternary glaciations by permitting direct analysis of the fragmentary glacial stratigraphic record (Zreda and Phillips, 
1995). Despite this progress, TCN dating can be complicated by geologic processes which result in pre- or post-depositional exposure of rock surfaces and which account for apparent TCN ages that pre- or post-date the assumed age of the landform (Applegate et al., 2010). Of these, post-depositional erosion, exhumation and shielding have been shown to profoundly influence TCN age distributions (Briner et al., 2005; Zech et al., 2005; Heyman et al., 2011; Stübner et al., 2017; Chevalier and Replumaz, 2019).

To avoid geologic outliers, researchers select samples based on the depositional context and characteristics of individual surfaces. Previous studies have advocated sampling:

- boulders on moraine crests or on flat, stable surfaces (Gosse et al., 1995),

- the tallest boulders, to minimise the likelihood of postdepositional shielding (Heyman et al., 2016),

- the largest boulders or boulders embedded in the moraine matrix (Ivy-Ochs et al., 2007), to minimise the likelihood of post-depositional instability,

- well-rounded boulders which preserve evidence of glacial transport (Darvill et al., 2015), to minimise the likelihood of pre-depositional exposure.

However, while these criteria have good qualitative reasoning, many have not been tested quantitatively. In turn, further work is required to test existing criteria for sample selection and to develop quantitative methods which minimise the effects of geologic processes (Dortch et al., 2013, 2021). These developments have the potential to significantly improve the robustness of TCN datasets and the chronological utility of the moraine record (Applegate et al., 2012). Within this context, this paper focuses on a fundamental component of TCN sample selection; the effect of moraine crest sampling on boulder exposure age. Of the above criteria, boulder location is critical, as boulders on moraine crests are prioritised, while those on moraine slopes are typically rejected, irrespective of their individual characteristics.

While this approach is qualitatively sound, early numerical models of moraine evolution predicted the greatest groundlowering at moraine crests (Hallet and Putkonen, 1994; Putkonen and Swanson, 2003) with a period of maximum instability as glaciers retreat and as oversteepened ice-proximal slopes erode and stabilise (Porter and Swanson, 2008). However, moraines continue to degrade through time as a function of moraine height and sedimentology (Putkonen and Swanson, 2003; Putkonen et al., 2008; Schaller et al., 2009), as diffusive processes remove finegrained material from moraine crests and deposit material at the base of moraine slopes (Applegate et al., 2010). Over time, these processes drive exhumation of boulders which have been shielded from cosmogenic exposure. In turn, the age distribution of moraine crest boulders may primarily reflect an initial stabilisation phase ( $\sim 1 \mathrm{ka}$; Briner et al., 2005; Dortch et al., 2010), modified by the ongoing process of moraine degradation, rather than the timing of initial moraine deposition. In contrast, slope diffusion models and lichenometric methods predict relative stability on moraine slopes (Hallet and Putkonen, 1994; Putkonen and O'Neal, 2006), but these are rarely sampled for TCN, in part due to the perceived risk that boulders may rotate, shift or roll throughout the lifetime of the moraine. This dichotomy between model predictions and sampling procedures raises a fundamental and currently unanswered question: should moraine crests or moraine slopes be prioritised in TCN sample selection?

To address this uncertainty, we utilise 19 new and published ${ }^{10} \mathrm{Be}$ and ${ }^{36} \mathrm{Cl}$ TCN ages and 635 Schmidt hammer calibratedexposure ages ( $\mathrm{SH} ; 19,050 \mathrm{SH} R$-values) from ice-marginal moraines in the northern and southern Pyrenees. Weathering-based analyses are utilised here to enable intensive sampling of boulders across the moraine surface, with results verified against independent TCN ages. In total, these data provide the first quantitative assessment of the relative utility of moraine crest and moraine slope sampling.

\section{Methods}

\subsection{Moraine selection}

Six moraines of varying age, geomorphology and sedimentology were selected in the Pyrenees (Fig. 1); a mountain range which was extensively glaciated during Pleistocene cold stages (see Fig. 1F; Calvet et al., 2011). Moraines were selected to encompass the primary deglaciation phases of the Pyrenees since the global Last Glacial Maximum (LGM) and all feature large populations of quartz-rich granitic moraine boulders, sourced from Axial zone granite outcrops in the Arànser, Gave de Pau and Noguera Rigaborçana glaciated valleys (Fig. 1E), and which are suitable for ${ }^{10} \mathrm{Be}$ dating. While this focused approach does not comprise all moraine types or depositional settings, these sites do encompass a range of moraine types commonly found in cirque and valley landsystems and which are often priority targets for TCN dating (i.e. $\leq$ LGM)

Selected moraines include both left (north) and right (south) latero-frontal moraines in the Arànser catchment, Cerdanya (Fig. 2A). These moraines are matrix-rich (matrix-supported), steep-sided $\left(30-40^{\circ}\right)$, heavily forested (Mountain pine: Pinus uncinata), and record the maximum ice extent of the Arànser glacier during the Würmian cold stage (110 - 11.7 ka; Calvet et al., 2011). The right latero-frontal moraine has previously been dated using ${ }^{36} \mathrm{Cl}(n=2$; Palacios et al., 2015). To supplement these data, a further 10 boulders were selected for ${ }^{10} \mathrm{Be}$ analysis (Table 1 ). Methods used for sample preparation, ${ }^{10} \mathrm{Be}$ measurement and exposure age calculation are detailed in the Supplementary Information.

On the north side of the Pyrenees, matrix-rich lateral moraines were selected in the Gave de Pau catchment (Fig. 2B). At least two neighbouring $(\sim 60 \mathrm{~m})$ but distinct lateral moraine ridges have been identified (Soum d'Ech moraines; Fig. 1D), with the outer moraine previously dated using ${ }^{10} \mathrm{Be}(n=4$; Rodés, 2008). As at Arànser, these moraines likely correspond to the Würmian MIE but their distinctive morphologies (multiple nested ridges $v s$. a single large moraine) likely reflects a topographic control on moraine deposition (open topography vs. confined valley; Barr and Lovell, 2014; Palacios et al., 2015).

On the south side of the Pyrenees, and in the Val de Molières catchment of the Noguera Rigaborçana, sampled sites include the boulder-rich (clast-supported), matrix-poor Outer Pleta Naua terminal moraine (Fig. 3B, 1B), previously assigned to Greenland Stadial 1 based on ${ }^{10} \mathrm{Be}(n=3$; Pallàs et al., 2006), and the Tallada cirque moraine (Fig. 3A, 1A), which consists of a single sharpcrested, arcuate terminal moraine with two minor ice-proximal ridges. Both the Outer Pleta Naua and Tallada moraines are primarily composed of wedged angular boulders, with little or no sediment matrix. Although undated, the Tallada moraine is assumed to be late-Holocene in age, as evidenced by minimal boulder weathering (Pallàs et al., 2006), while its elevation ( $2400 \mathrm{~m})$, topographic setting (enclosed cirque; $\sim 0.16 \mathrm{~km}^{2}$ ) and aspect (NNE) likely contribute to the inter-annual preservation of a small snowfield $\left(\sim 0.03 \mathrm{~km}^{2}\right)$. These factors may have enabled glacier growth or re-advance during more recent climatic periods (e.g. the Little Ice Age).

\subsection{Sampling approach}

To investigate the depositional and post-depositional histories of these moraines, glacial boulders were selected to cover the entire moraine surface, including the moraine crest $(\mathrm{C})$, the inner 

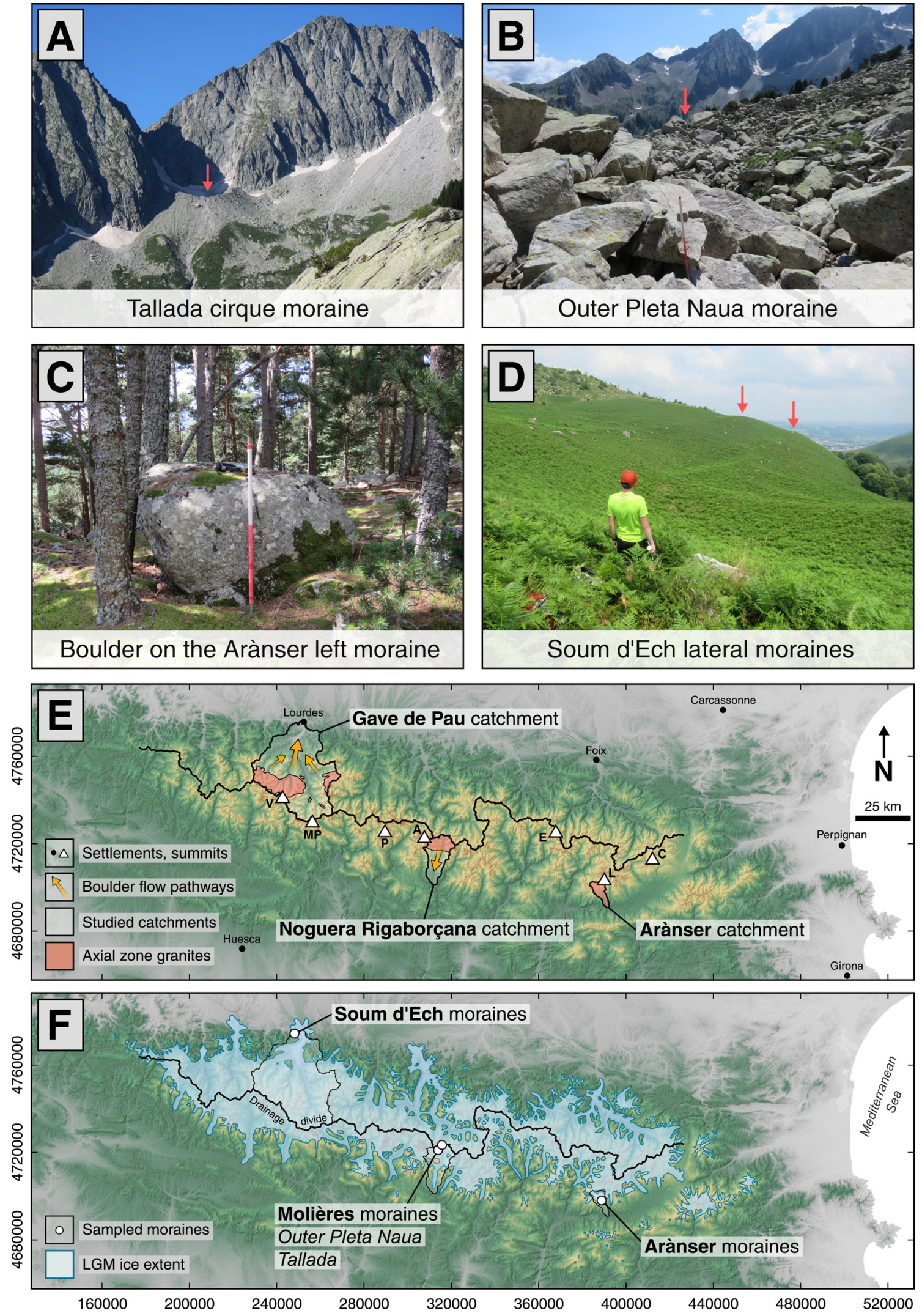

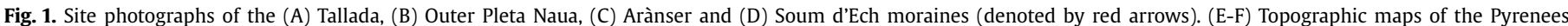

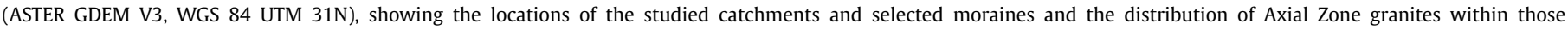

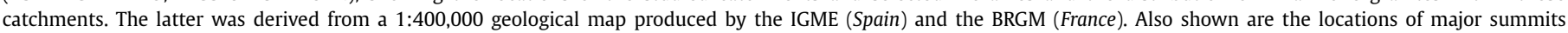

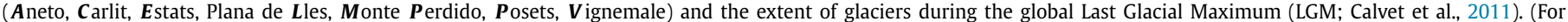
interpretation of the colours in the figure(s), the reader is referred to the web version of this article.) 


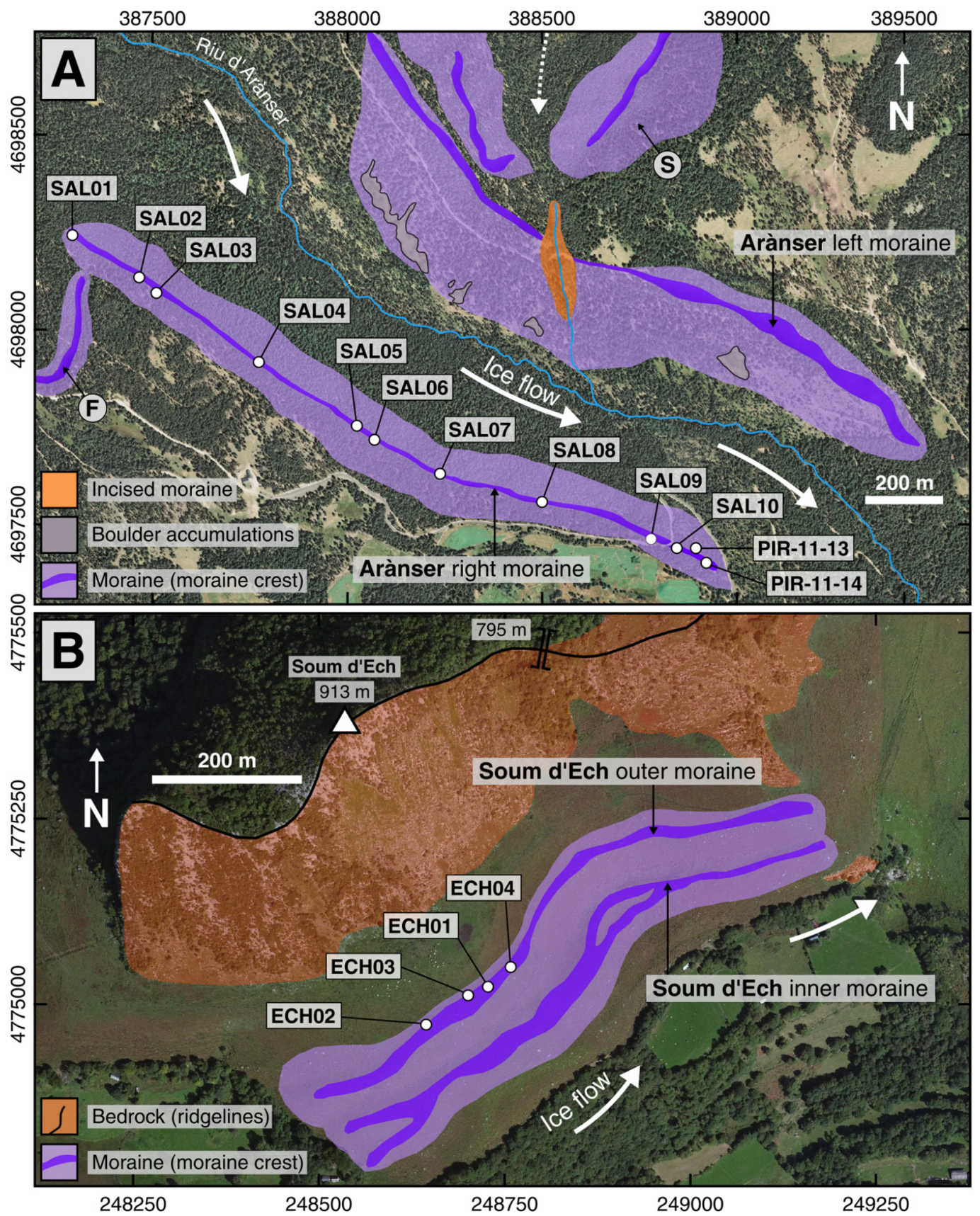

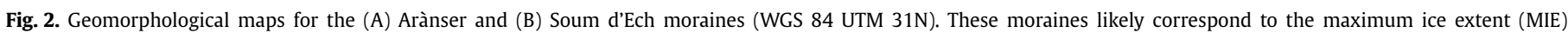

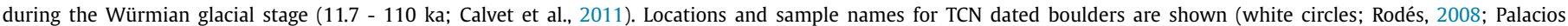

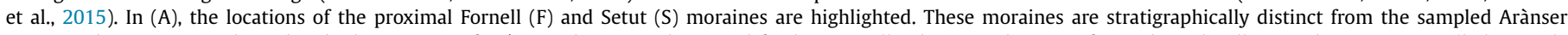

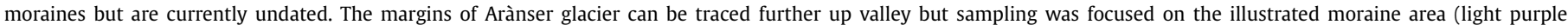
shading) in which the moraine margins are easily delineated ( $\leq 2 \mathrm{~km}$ from glacier terminus).

ice-proximal slope (IS) and the outer ice-distal slope (OS), while the number of selected boulders varied as a function of moraine size ( $n=60-275$ ). In turn, boulder selection was primarily motivated by spatial location and the construction of a dense matrix of sampling points, rather than individual boulder characteristics. Each boulder was sampled using an N-type Schmidt hammer (SH) to assess the relative degree of weathering following the sampling approach of Tomkins et al. (2018a). All boulders were of sufficient size (> $25 \mathrm{~kg}$; Sumner and Nel, 2002) and sampled areas were free of surface discontinuities (Williams and Robinson, 1983) and lichen (Matthews and Owen, 2008). Thirty $R$-values were recorded for each boulder by a single operator and no outliers were removed following Niedzielski et al. (2009). Schmidt hammer functioning was assessed regularly using the manufacturer's test anvil, with instrument and age calibration performed following Tomkins et al. (2018a). In total, 635 moraine boulders were sampled across the selected sites and 19,050 SH $R$-values were generated. To complement these data, the dimensions, surface features and depositional context of each sampled boulder were recorded (see Supplementary Information).

Schmidt hammer $R$-values correspond to the degree of surface weathering, assuming minimal lithological variation between tested rock surfaces (McCarroll, 1989), and are inversely proportional to surface exposure age. The rate and style of weathering 
Table 1

Summary data for terrestrial cosmogenic nuclide exposure ages from the sampled moraines ${ }^{\mathrm{a}}$.

\begin{tabular}{|c|c|c|c|c|c|c|c|c|c|}
\hline Moraine & Name & Isotope & $\begin{array}{l}\text { Latitude } \\
\left({ }^{\circ}\right)\end{array}$ & $\begin{array}{l}\text { Longitude } \\
\left({ }^{\circ}\right)\end{array}$ & $\begin{array}{l}\text { Elevation } \\
(\mathrm{m})\end{array}$ & $\begin{array}{l}\text { Age } \\
\text { (ka) }\end{array}$ & $\begin{array}{l}\text { Internal } \\
\pm(\mathrm{ka})\end{array}$ & $\begin{array}{l}\text { External } \\
\pm(\mathrm{ka})\end{array}$ & $\mathrm{SH} R \pm \mathrm{SEM}^{\mathrm{b}}$ \\
\hline \multirow[t]{3}{*}{ Outer Pleta Nauac } & OPN01 & ${ }^{10} \mathrm{Be}$ & 42.6365 & 0.7399 & 2217 & 13.2 & 1.3 & 1.6 & - \\
\hline & OPN02 & ${ }^{10} \mathrm{Be}$ & 42.6365 & 0.7406 & 2197 & 13.0 & 1.7 & 2.0 & $51.68 \pm 0.5$ \\
\hline & OPN03 & ${ }^{10} \mathrm{Be}$ & 42.6365 & 0.7409 & 2195 & 12.6 & 1.2 & 1.5 & - \\
\hline \multirow[t]{8}{*}{ Arànser (Right) ${ }^{\mathrm{d}}$} & SAL-01 & ${ }^{10} \mathrm{Be}$ & 42.4283 & 1.6300 & 2000 & 17.6 & 0.6 & 1.5 & $47.57 \pm 0.83$ \\
\hline & SAL-02 & ${ }^{10} \mathrm{Be}$ & 42.4273 & 1.6321 & 1983 & 19.2 & 0.6 & 1.5 & $45.07 \pm 0.84$ \\
\hline & SAL-04 & ${ }^{10} \mathrm{Be}$ & 42.4254 & 1.6358 & 1933 & 18.0 & 0.6 & 1.5 & $47.57 \pm 0.84$ \\
\hline & SAL-05 & ${ }^{10} \mathrm{Be}$ & 42.4240 & 1.6389 & 1912 & 17.0 & 0.9 & 1.6 & $48.9 \pm 0.77$ \\
\hline & SAL-06 & ${ }^{10} \mathrm{Be}$ & 42.4237 & 1.6395 & 1908 & 19.2 & 0.6 & 1.5 & $44.53 \pm 0.74$ \\
\hline & SAL-07 & ${ }^{10} \mathrm{Be}$ & 42.4229 & 1.6415 & 1896 & 16.7 & 0.5 & 1.4 & $47.43 \pm 0.96$ \\
\hline & SAL-08 & ${ }^{10} \mathrm{Be}$ & 42.4223 & 1.6447 & 1863 & 17.1 & 0.6 & 1.4 & $47.7 \pm 0.9$ \\
\hline & SAL-09 & ${ }^{10} \mathrm{Be}$ & 42.4215 & 1.6481 & 1820 & 20.7 & 0.9 & 1.7 & $44.77 \pm 0.8$ \\
\hline \multirow[t]{4}{*}{ Soum d'Ech ${ }^{\mathrm{e}}$} & ECH01 & ${ }^{10} \mathrm{Be}$ & 43.0863 & -0.0870 & 776 & 19.7 & 3.2 & 3.6 & $42.43 \pm 0.98$ \\
\hline & $\mathrm{ECHO2}$ & ${ }^{10} \mathrm{Be}$ & 43.0858 & -0.0880 & 778 & 59.0 & $43.2^{\mathrm{f}}$ & 43.0 & - \\
\hline & ECHO3 & ${ }^{10} \mathrm{Be}$ & 43.0862 & -0.0873 & 779 & 17.2 & 3.3 & 3.5 & $38.86 \pm 1.11$ \\
\hline & ECHO4 & ${ }^{10} \mathrm{Be}$ & 43.0865 & -0.0867 & 781 & 16.8 & 3.0 & 3.3 & $38.77 \pm 1.05$ \\
\hline
\end{tabular}

${ }^{a}$ Full sample information used for exposure age calculation is provided in the Supplementary Information or is available on GitHub: https://github.com/matt-tomkins/moraine-crest-or-slope. ${ }^{b}$ Mean of $30 \mathrm{SH} R$-values \pm the Standard Error of the Mean. ${ }^{\mathrm{c}} \mathrm{OPN}$ samples from Pallàs et al. (2006). ${ }^{d}$ PIR samples from Palacios et al. (2015). ${ }^{e}$ ECH samples from Rodés (2008). ${ }^{\mathrm{f}}$ Measurement error, see Rodés (2008).

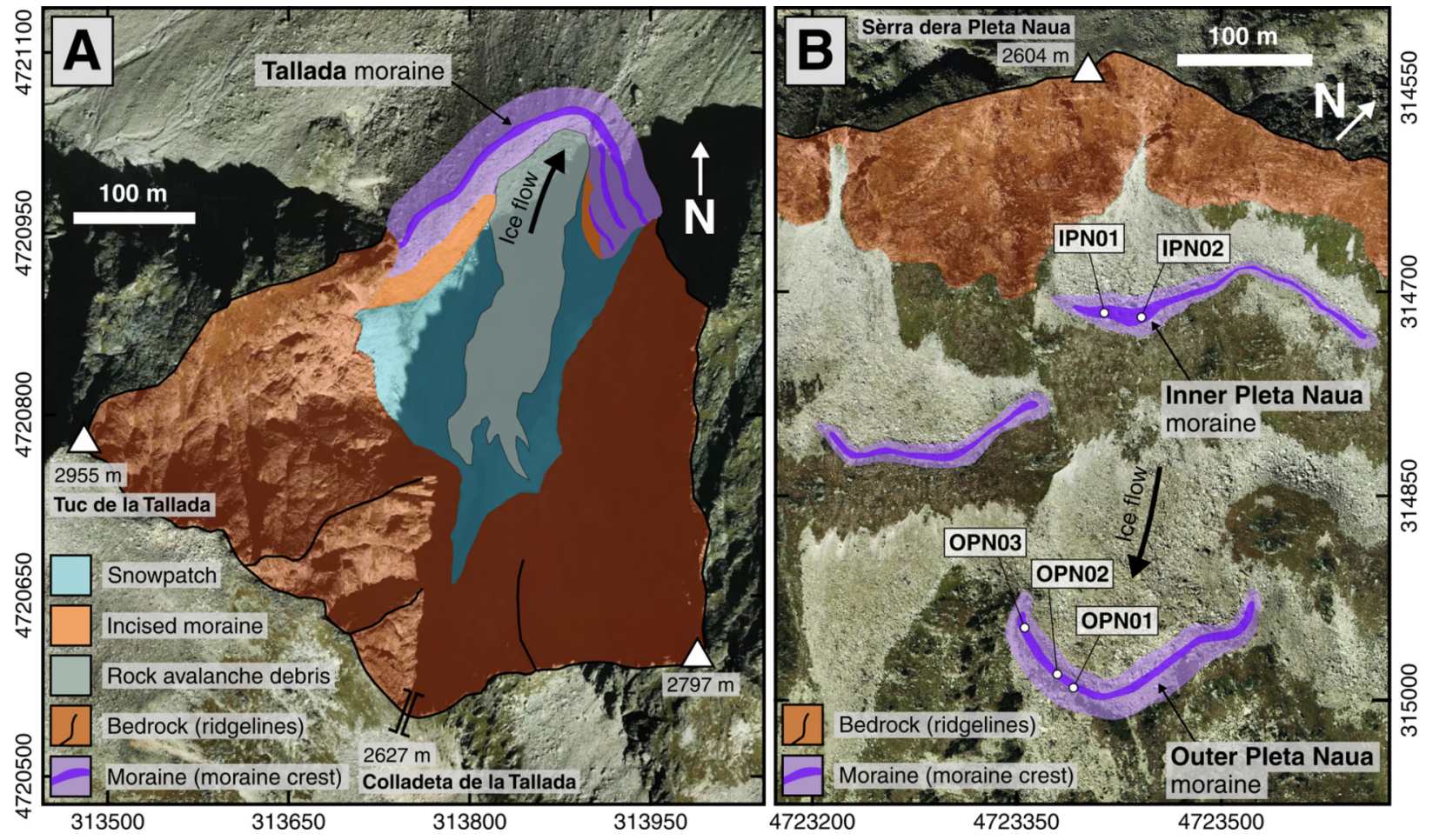

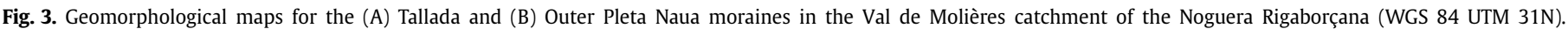

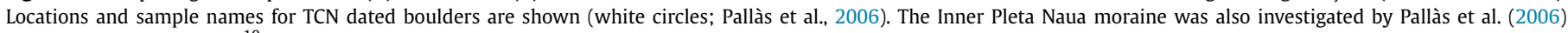

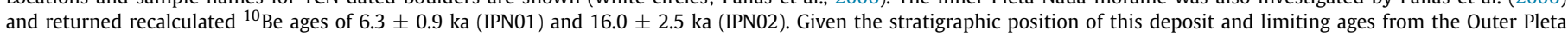
Naua and Molières moraines (MUL01 = $14.9 \pm 2.6$ ka, MUL03 $=14.9 \pm 1.9$ ka; Pallàs et al., 2006), it appears likely that IPN02 is affected by inheritance.

may also be modified by climate (Riebe et al., 2004; Portenga and Bierman, 2011; Marrero et al., 2018). At the intra-landform scale, lithologic-climatic variability is absent as all sampled boulders share a common source area and climatic regime. At the interlandform scale, variability in rock type is minimal, as all sampled boulders were coarse- to medium-grained granites and granodiorites. Finally, while regional climatic variability could account for variability in weathering rates across the studied sites, previous work has shown that rates of sub-aerial weathering of granite are consistent over large spatial scales for regions of similar climate (Tomkins et al., 2018b).

\subsection{Calculating SH-calibrated exposure ages}

As granitic lithologies have proved effective for calibratedrelative age dating, SH $R$-values are used here as a proxy for exposure age based on a ${ }^{10} \mathrm{Be}-\mathrm{SH}$ calibration dataset developed by Tomkins et al. (2018b). This dataset comprises $52{ }^{10} \mathrm{Be}$ ages, 


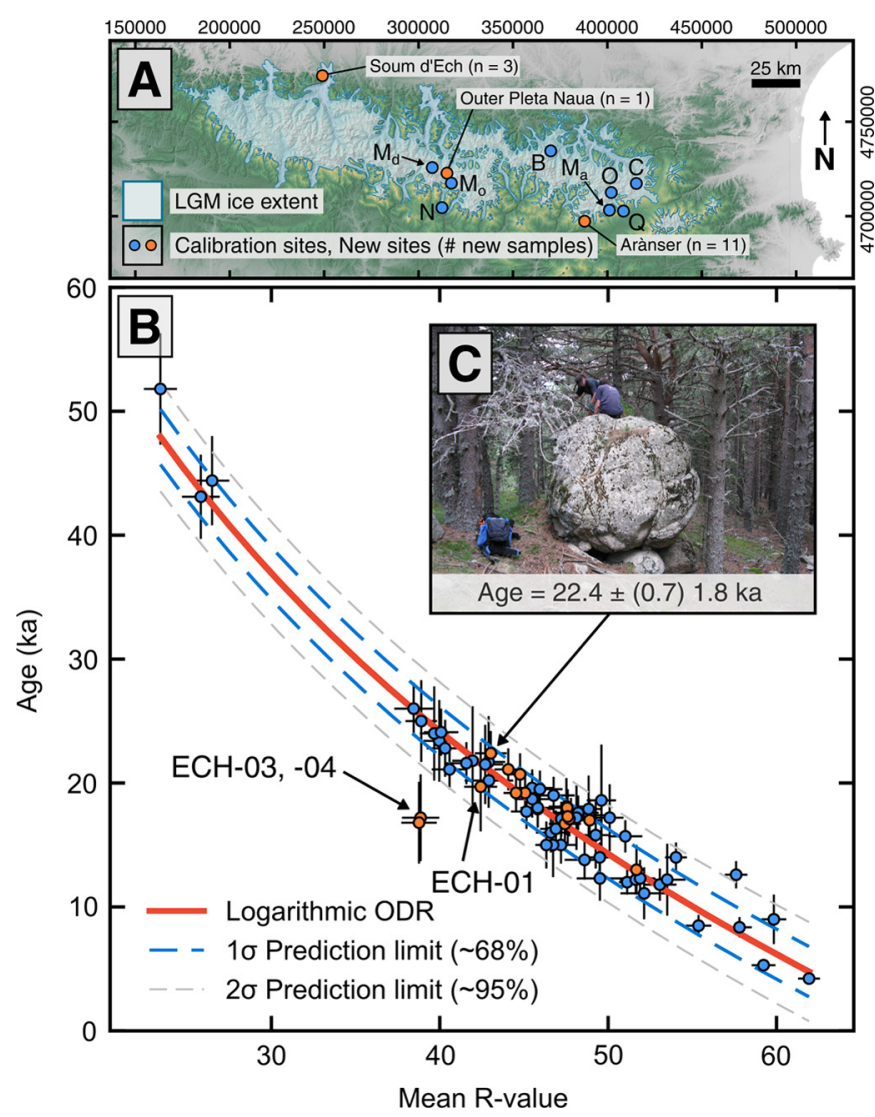

Fig. 4. (A) Location of exposure age calibration sites (blue points) in the Bassies (B, $n=6)$, Carlit $(C, n=3)$, Noguera Rigaborçana $(\mathrm{N}, n=4)$, Maladeta $\left(\mathrm{M}_{\mathrm{a}}, n=9\right)$, Malniu $\left(\mathrm{M}_{\mathrm{n}}, n=21\right)$, Molières $\left(\mathrm{M}_{0}, n=2\right)$, Orri $(\mathrm{O}, n=3)$ and Querol catchments $(\mathrm{Q}$, $n=6$ ). Underlying topography is ASTER GDEM V3 (WGS 84 UTM 31N). Also shown are the locations of sampled moraines (orange points; see Fig. $1 \mathrm{~F}$ ) and the maximum ice extent (MIE) during the global Last Glacial Maximum (LGM; Calvet et al., 2011). (B) Monte Carlo-derived orthogonal distance regression (ODR) between 54 ${ }^{10} \mathrm{Be}$ exposure ages (blue points \pm external age uncertainty) and their corresponding $\mathrm{SH} R$-values (mean of $30 R$-values \pm Standard Error of the Mean; Tomkins et al., 2018b), plus $1 \sigma$ (blue dashed lines) and $2 \sigma$ prediction limits (grey dashed lines). Independent TCN samples $\left({ }^{10} \mathrm{Be},{ }^{36} \mathrm{Cl}\right)$ from the studied moraines $(n=15)$ are shown as orange points. Inherited outliers from the original calibration dataset ( $n=2$; Tomkins et al., 2018b) are not shown for clarity. (C) Example of a ${ }^{10} \mathrm{Be}$ dated boulder from the Arànser right moraine (SAL-10).

distributed between $4.2 \pm 0.3 \mathrm{ka}$ and $51.8 \pm 4.5 \mathrm{ka}$ (Fig. 4), obtained from granite and granodiorite glacial boulders and glaciallysculpted bedrock from across the central and eastern Pyrenees and their corresponding SH $R$-values (Tomkins et al., 2018b). This dataset has been updated to include two additional ${ }^{10}$ Be dated surfaces from the Val de Molières (MUL01 and MUL03; Pallàs et al., 2006; see Supplementary Table 1).

To utilise these data, ${ }^{10} \mathrm{Be}$ ages were recalculated using the CRONUS Earth Web Calculator (Version 2.0; Marrero et al., 2016, available at: http://cronus.cosmogenicnuclides.rocks/2.0/, accessed: $01 / 09 / 2020)$, relative to the production rate dataset in Borchers et al. (2016) and the time-dependent Lm scaling scheme (Lal, 1991; Stone, 2000), and assuming $0 \mathrm{~mm} \mathrm{ka}^{-1}$ erosion. Recalculated ${ }^{10} \mathrm{Be}$ ages are minimum estimates, as no corrections were made for shielding by snow, sediment or vegetation, surface erosion, or isostatic adjustment. To ensure consistency, all ${ }^{10} \mathrm{Be}$ and ${ }^{36} \mathrm{Cl}$ TCN ages discussed in this paper have been recalculated using these input parameters. This includes published ages from Pallàs et al. (2006), Rodés (2008), and Palacios et al. (2015), in addition to the 10 new ${ }^{10} \mathrm{Be}$ dated samples from the Arànser catchment. Full sample details used for exposure age calculation are provided in the Supplementary Information.
In turn, a ${ }^{10} \mathrm{Be}-\mathrm{SH}$ calibration curve was constructed using logarithmic orthogonal distance regression (ODR, Boggs and Rogers, 1990) which minimises orthogonal residuals to account for measurement uncertainties in both the independent and dependent variables. We utilise Monte Carlo simulations to explicitly incorporate measurement errors; an approach which is preferable to a weighted ODR which requires unnecessary assumptions regarding weighting constants and is biased by TCN age-uncertainty collinearity (Ivy-Ochs et al., 2007; Dortch et al., 2021). Our analytical procedure, which returns prediction estimates $(1 \sigma)$ of \pm $2.0-2.3 \mathrm{ka}$, is described fully in the Supplementary Information and has been implemented in SHED-Earth (http://shed.earth), an online calculator developed to enable wider and more consistent application of our approach (Tomkins et al., 2018a). To assess the accuracy of the ${ }^{10} \mathrm{Be}-\mathrm{SH}$ calibration curve, $15{ }^{10} \mathrm{Be}$ and ${ }^{36} \mathrm{Cl}$ ages from the studied moraines were located and re-sampled with the $\mathrm{SH}$.

Based on this calibration curve, mean $R$-values from the 635 sampled boulders were converted into "SH-calibrated exposure ages" through interpolation. While uncertainty estimates for individual SH-calibrated exposure ages are larger than typical uncertainties associated with individual TCN exposure ages, landform age estimates can be of comparable precision to established techniques when derived from large SH datasets (e.g. $n$ boulders $\geq 30$; Tomkins et al., 2018b) and when appropriate statistical approaches for outlier identification and error propagation are employed (Applegate et al., 2012; Dortch et al., 2013, 2021).

\subsection{Calculating landform ages}

To determine the timing of moraine deposition at each site, we analysed the distribution of SH-calibrated exposure ages using the Probabilistic Cosmogenic Age Analysis Tool (P-CAAT Version 1.0; Dortch et al., 2021). This method builds on the earlier work of Dortch et al. (2013) and utilises non-linear curve fitting and a Monte Carlo style approach to isolate component Gaussian distributions to account for positive (prior exposure) and negative skew (incomplete exposure) of age datasets. The results of this analysis are presented in Fig. 5 and Table 2. To assess the validity of these landform ages, we compared these data to the distribution of ${ }^{10} \mathrm{Be}$ and ${ }^{36} \mathrm{Cl}$ ages from the studied landforms (Table 1; Pallàs et al., 2006; Rodés, 2008; Palacios et al., 2015).

Based on landform age analysis, individual boulders were sorted into "good" and "bad" groups, which are defined by the $2 \sigma$ (95\%) age boundaries of the calculated landform age. Boulders which returned SH-calibrated exposure ages within $2 \sigma$ of the landform age were classed as "good", while those younger or older than the landform age $(>2 \sigma)$ were classed as "bad". Selection of a broad $2 \sigma$ threshold is appropriate given the measurement uncertainties associated with SH sampling, in addition to the systematic and geologic uncertainties inherited from TCN dating. Logistic analysis is used to distinguish boulders which correspond to the timing of moraine deposition or initial stabilisation ("good") from those which are likely compromised by pre- or post-depositional exposure ("bad").

\subsection{Spatial analysis}

The spatial distribution of "good" and "bad" boulders was analysed using global and local Moran's I spatial autocorrelation and based on a row-standardised distance-band weights matrix, where the distance band threshold is the minimum distance required to ensure that each boulder has at least two neighbours (Table 3). The Python implementation is available on GitHub: https:/github.com/ matt-tomkins/moraine-crest-or-slope. At the global level, Moran's I was used to assess whether the overall clustering of the data 

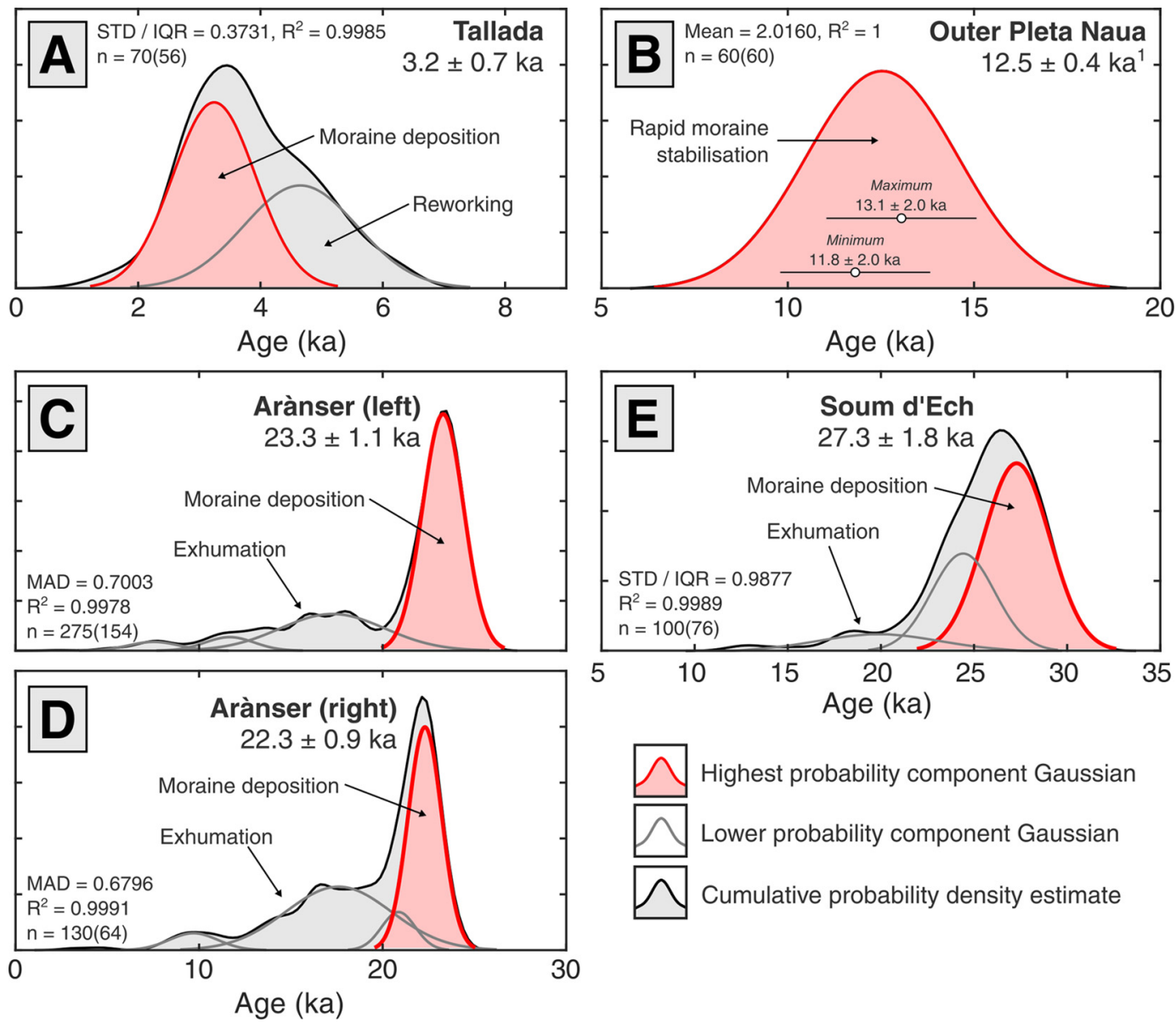

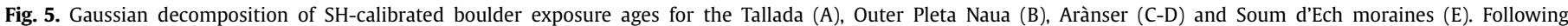

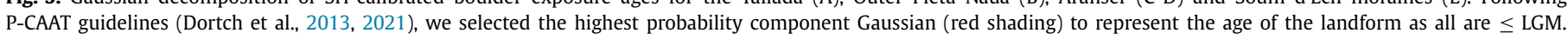

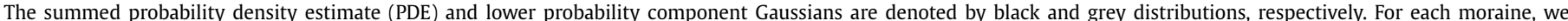

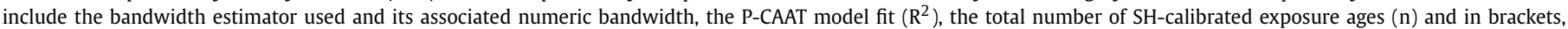

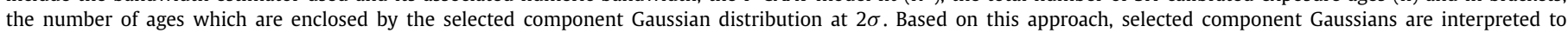

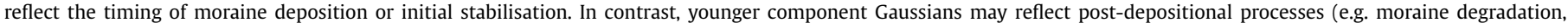
boulder exhumation or instability) while older component Gaussians likely incorporate pre-depositional processes (e.g. reworking of glacial deposits).

Table 2

Age statistics for the sampled moraines.

\begin{tabular}{|c|c|c|c|c|c|c|c|c|c|c|c|}
\hline Moraine & Group & Method $^{\mathrm{a}}$ & Bandwidth $^{\mathrm{b}}$ & Model $\mathrm{fit}^{\mathrm{c}}$ & $\begin{array}{l}\text { Age } \\
(\mathrm{ka})^{\mathrm{d}}\end{array}$ & $\mathrm{IQR}^{\mathrm{e}}$ & Skew & Normality $^{\mathrm{f}}$ & $\begin{array}{l}\text { Young } \\
(\%)^{g}\end{array}$ & $\begin{array}{l}\text { Good } \\
(\%)^{g}\end{array}$ & $\begin{array}{l}\text { Old } \\
(\%)^{g}\end{array}$ \\
\hline Tallada & - & STD / IQR & 0.3731 & 0.9985 & $3.2 \pm 0.7$ & $1.2 \mathrm{ka}$ & 0.34 & 0.44 & 6 & 80 & 14 \\
\hline Outer Pleta Naua & - & Mean & 2.016 & 1 & $12.5 \pm 0.4^{\mathrm{h}}$ & $0.6 \mathrm{ka}$ & -0.24 & 0.07 & 0 & 100 & 0 \\
\hline \multirow[t]{2}{*}{ Arànser } & Left & MAD & 0.7003 & 0.9978 & $23.3 \pm 1.1^{\mathrm{i}}$ & $7.9 \mathrm{ka}$ & -1.02 & $<0.01$ & 44 & 56 & 0 \\
\hline & Right & MAD & 0.6796 & 0.9991 & $22.3 \pm 0.9$ & $6.9 \mathrm{ka}$ & -1.13 & $<0.01$ & 51 & 49 & 0 \\
\hline \multirow[t]{3}{*}{ Soum d'Ech } & Outer & STD / IQR & 1.0734 & 0.998 & $26.2 \pm 2.5$ & $3.5 \mathrm{ka}$ & -1.49 & $<0.01$ & - & - & - \\
\hline & Inner & STD / IQR & 1.1661 & 0.9996 & $26.1 \pm 1.7$ & $3.5 \mathrm{ka}$ & -1.05 & $<0.01$ & - & - & - \\
\hline & Combined & STD / IQR & 0.9877 & 0.9989 & $27.3 \pm 1.8$ & $3.6 \mathrm{ka}$ & -1.49 & $<0.01$ & 24 & 76 & 0 \\
\hline
\end{tabular}

${ }^{\mathrm{a}, \mathrm{b}}$ Method used for kernel density estimation (see Dortch et al., 2021) and its associated numeric bandwidth. ${ }^{\mathrm{c}}$ All model $p$ values < 0.01 . ${ }^{\mathrm{d}}$ Reported uncertainty $( \pm)$ is the $1 \sigma$ bounds $(68 \%)$ of the highest probability component Gaussian, unless stated otherwise. ${ }^{\mathrm{e}}$ Interquartile range. ${ }^{\mathrm{f}}$ Shapiro-Wilk test for normality $p$ values. ${ }^{\mathrm{g}}$ Based on the landform age $\pm 2 \sigma .{ }^{\mathrm{h}}$ Arithmetic mean of 60 samples \pm total uncertainty. ${ }^{\mathrm{i}}$ Calculation based on a reduced dataset of 274 samples. Sample ARL-192 (1.97 $\pm 2.06 \mathrm{ka})$ is more than three standard deviations from the mean of the remaining samples and was removed for program stability.

was significantly different from a random distribution. For datasets that are non-random ( $p<0.05$ ), local Moran's $I$ was used to identify the location of statistically significant boulder clusters (Fig. 6). Current sampling approaches are based on the qualitatively-sound but quantitatively-untested assumptions that (i) the distribution of "good" boulders is non-random, and that (ii) "good" clusters are more likely on moraine crests. These assumptions can be explicitly tested for the studied moraines using global and local Moran's I respectively.

\subsection{Sensitivity analysis}

The above analyses provide important information on the relative occurrence and spatial clustering of "good" and "bad" boulders for moraines of varying age and morphology. However, this logistic classification is ultimately dependent on the calculated landform age, which will vary depending on the choice of numeric bandwidth estimator and the size and clustering of the input dataset (Dortch et al., 2021). 
Table 3

Spatial statistics for the sampled moraines.

\begin{tabular}{|c|c|c|c|c|c|c|c|c|c|c|c|}
\hline \multirow[b]{2}{*}{ Moraine } & \multirow[b]{2}{*}{ Type } & \multicolumn{4}{|c|}{ Number of samples } & \multicolumn{3}{|l|}{ Global Morans I } & \multicolumn{3}{|c|}{ "Good" boulder (\%) } \\
\hline & & Total & IS $^{\mathrm{a}}$ & $\mathrm{C}^{\mathrm{a}}$ & $\mathrm{OS}^{\mathrm{a}}$ & Distance threshold $(\mathrm{m})^{\mathrm{b}}$ & $I$ & Simulated $p$ value ${ }^{c}$ & $\mathrm{IS}^{\mathrm{a}}$ & $\mathrm{C}^{\mathrm{a}}$ & $\mathrm{OS}^{\mathrm{a}}$ \\
\hline Tallada & Terminal & 70 & 16 & 29 & 25 & 21.6 & 0.0980 & 0.0719 & 80 & 79 & 81 \\
\hline Outer Pleta Naua & Terminal & 60 & 20 & 20 & 20 & 23.9 & $N A^{d}$ & $N A^{\mathrm{d}}$ & 100 & 100 & 100 \\
\hline Arànser (Left) & Latero-frontal & 275 & 199 & 51 & 25 & 59.5 & 0.0915 & 0.0064 & 53 & 57 & 76 \\
\hline Arànser (Right) & Latero-frontal & 130 & 57 & 33 & 40 & 66.3 & 0.0651 & 0.1194 & 63 & 36 & 40 \\
\hline Soum d'Ech & Laterals & 100 & 37 & 50 & 13 & 51.1 & 0.1519 & 0.0106 & 76 & 72 & 81 \\
\hline
\end{tabular}

${ }^{a}$ Inner ice-proximal slope (IS), moraine crest (C) and outer ice-distal slope (OS). ${ }^{b}$ Defined as the minimum distance required to ensure that each boulder has at least two neighbours. ${ }^{c} p$ values $>0.05$ support no statistically significant spatial clustering. $p$ values $\leq 0.05$ are consistent with a non-random distribution and spatial clustering of the input data. ${ }^{\mathrm{d}}$ Spatial autocorrelation was not possible for the Outer Pleta Naua moraine as all boulders were classed as "good" based on the $2 \sigma$ threshold.

To evaluate the reproducibility of our results, sensitivity testing was performed to evaluate the number of samples required to reproduce the estimated landform age based on $1 \sigma$ and $2 \sigma$ thresholds. The full analytical approach is described in the Supplementary Information and the results are presented in Fig. 7B.

\section{Results}

\subsection{SH-calibrated exposure ages}

There is a strong correlation between recalculated ${ }^{10} \mathrm{Be}$ ages and their corresponding SH $R$-values (Fig. $4 ; n=54$ ). Moreover, of the $15{ }^{10} \mathrm{Be}$ and ${ }^{36} \mathrm{Cl}$ dated boulders re-sampled with the $\mathrm{SH}$, the majority closely match the existing calibration dataset $(n=13)$. These observations indicate that when lithological variation is minimised, the relative degree of rock surface weathering can be used as a proxy for surface exposure age.

Exceptions to this correlation are samples ECH03 $(17.2 \pm 3.5$ ka) and ECH04 (16.8 $\pm 3.3 \mathrm{ka})$ from the Soum d'Ech moraines (Rodés, 2008) which are significantly more weathered $(\sim 38 R)$ than their corresponding ${ }^{10} \mathrm{Be}$ ages would predict $(\sim 47 R)$. This difference likely reflects sub-surface weathering prior to boulder exhumation. However, the scale of this influence is unlikely to be universal given the close correspondence between sample ECH01 $(19.7 \pm 3.6 \mathrm{ka})$ and the existing calibration dataset (see Fig. 4). While sub-surface weathering of boulders under thin soil cover $(\sim 25 \mathrm{~cm})$ can occur (Darmody et al., 2005), boulders are often protected from weathering by sediment burial, as evidenced by the emergence of unweathered boulders from glacial tills and alluvium (Ehlmann et al., 2008). In turn, as SH-calibrated exposure ages from the Soum d'Ech moraines may well incorporate the effects of both sub-aerial and sub-surface weathering, and could also be influenced by weathering rate variability (e.g. differences between the Atlantic- (wet) and Mediterranean-influenced (dry) Pyrenees), it is possible that the estimated depositional age is an overestimate.

\subsection{Landform ages}

Landform ages derived from SH-calibrated exposure ages and associated P-CAAT model parameters are reported in Table 2 (Dortch et al., 2021). Based on this approach, latero-frontal moraines in the Arànser catchment were deposited at $23.3 \pm 1.1 \mathrm{ka}$ (left) and $22.3 \pm 0.9 \mathrm{ka}$ (right). As these estimates are consistent within measurement uncertainties, and given the comparable morpho-stratigraphy of these deposits (Fig. 2A), we consider moraine deposition to be contemporaneous. No independent dating evidence is available for the left lateral moraine, but 12 TCN ages are now available for the right lateral moraine $\left({ }^{36} \mathrm{Cl}, n=2\right.$; ${ }^{10} \mathrm{Be}, n=10$ ). Using P-CAAT and selecting the oldest component Gaussian distribution that contains $\geq 3$ ages to represent the age of the landform (see Fig. 3 in Dortch et al., 2013), these data return a landform age of $21.5 \pm 2.2 \mathrm{ka}$ (Mean bandwidth estimator; Numeric bandwidth $=0.8108, R^{2}=0.9997, p<0.01$ ), while the oldest sample is $22.4 \pm 1.8 \mathrm{ka}$ (SAL-10). Both estimates are consistent within measurement uncertainties with the SH-derived landform ages.

In the Gave de Pau catchment, SH-calibrated exposure ages from the proximal Soum d'Ech lateral moraines return landform ages of $26.2 \pm 2.5 \mathrm{ka}$ (outer, $n=61$ ) and $26.1 \pm 1.7 \mathrm{ka}$ (inner, $n=39$ ). While these moraines are morpho-stratigraphically distinct, they cannot be statistically distinguished. It is possible that moraine deposition occurred within the resolution of our sampling approach, or that differences in moraine age have been masked by moraine stabilisation, degradation or sub-surface boulder weathering. As the temporal distribution of SH-calibrated exposure ages is near identical (Table 2), we assign these deposits a landform age of $27.3 \pm 1.8$ ka based on P-CAAT ( $n=100$; STD / IQR bandwidth estimator; Numeric bandwidth $=0.9877, \mathrm{R}^{2}=0.9989, p<0.01$ ), and perform subsequent analyses on the combined dataset for computational ease.

While this estimate is significantly older than the corresponding ${ }^{10} \mathrm{Be}$ ages $(16.8 \pm 3.3 \mathrm{ka}, 17.2 \pm 3.5 \mathrm{ka}, 19.7 \pm 3.6 \mathrm{ka}$; Rodés, 2008), it is consistent with limiting ${ }^{14} \mathrm{C}$ ages obtained from a proximal palaeolake sediment sequence at Lac de Lourdes (Reille and Andrieu, 1995). While the oldest radiometric ${ }^{14} \mathrm{C}$ ages from this over-deepened glacial basin are now considered suspect due to contamination from mineral carbon (Pallàs et al., 2006), a younger AMS ${ }^{14} \mathrm{C}$ age from glaciolacustrine clays suggests initial ice-free conditions by $24.1 \pm 0.4$ ka cal. BP (20.025 \pm 0.175 ka BP; Sample depth $=920-960 \mathrm{~cm}$ ), as calculated using IntCal 13 (Reimer et al., 2013), while an AMS ${ }^{14} \mathrm{C}$ age from an overlying organic rich layer (gyttja) indicates the culmination of glaciolacustrine sedimentation and deglaciation of the lower Gave de Pau by $18.8 \pm 0.3 \mathrm{ka}$ cal. BP $(15.460 \pm 0.150 \mathrm{ka}$ BP; Sample depth $=740-750 \mathrm{~cm}$; Reille and Andrieu, 1995). Based on these data, the younger ${ }^{10} \mathrm{Be}$ ages from Soum d'Ech can be considered suspect. Continued glacial occupation of the Soum d'Ech site until $\sim 19.7 \mathrm{ka}$, as inferred from the oldest ${ }^{10} \mathrm{Be}$ age $(\mathrm{ECH01} ; 19.7 \pm 3.6 \mathrm{ka})$, appears unlikely given initial deglaciation of low ground by $\sim 24.1 \mathrm{ka}$. Instead, it appears likely that the ECH samples are representative of final moraine stabilisation, rather than initial deposition. This interpretation is supported by sensitivity analysis (see Section 3.5), as the number of TCN ages $(n=3)$ is below the threshold required to consistently reproduce the landform age derived from the full dataset at $2 \sigma$ ( $n$ $=11)$ and $1 \sigma(n=41)$.

In the Val de Molières catchment of the Noguera Rigaborçana, recalculated ${ }^{10} \mathrm{Be}$ ages on the Outer Pleta Naua moraine range from $12.6 \pm 1.5$ ka to $13.2 \pm 1.6 \mathrm{ka}(n=3$; Pallàs et al., 2006). These estimates are consistent with the $\mathrm{SH}$-calibrated exposure ages, which range from $11.8 \pm 2.0 \mathrm{ka}$ to $13.1 \pm 2.0 \mathrm{ka}(n=60)$. As the SHcalibrated exposure ages conform to a normal distribution (Fig. 5B; Shapiro-Wilk test, $W=0.96, p=0.07$ ), are well-clustered $(\mathrm{IQR}=0.6$ ka), and return an excellent P-CAAT model fit with a single com- 


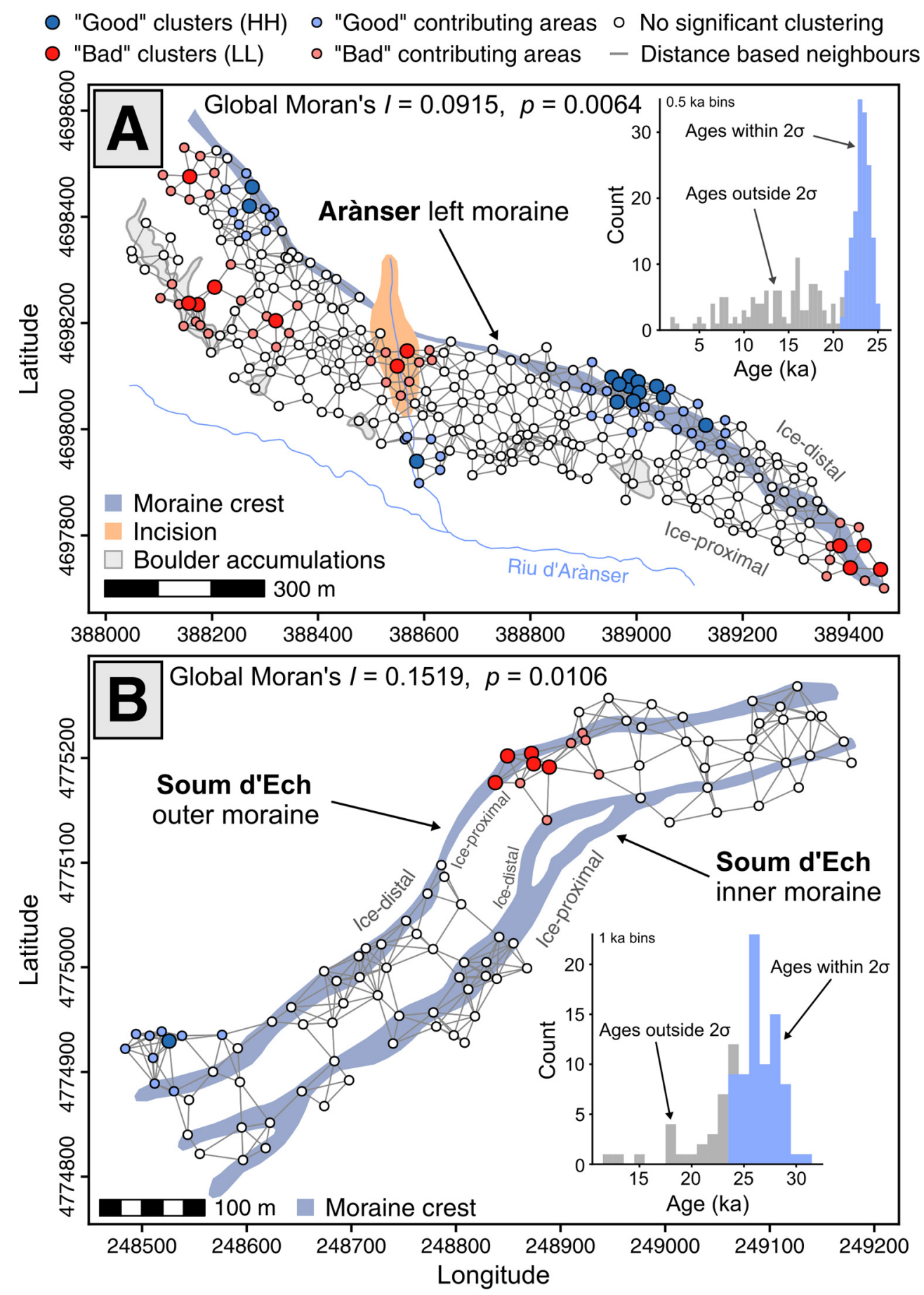

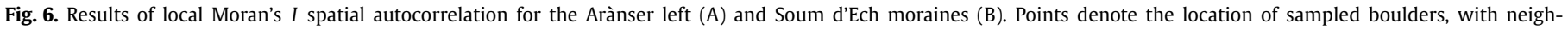

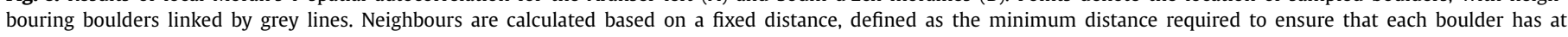

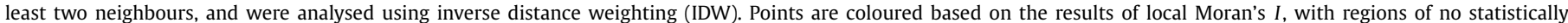

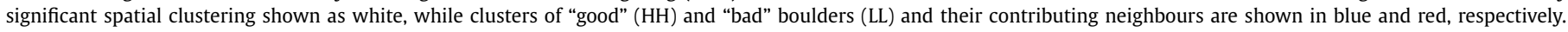

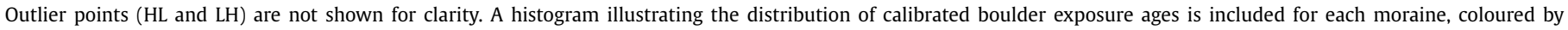
the "good" (blue) and "bad" components (grey).

ponent Gaussian $\left(\mathrm{R}^{2}=1, p<0.01\right)$, we use the arithmetic mean $(\bar{x})$ to represent the age of the landform and estimate the total uncertainty $(t)$ following Dortch et al. (2021) as follows:

$t=\sqrt{S U^{2}+G U^{2}}$

where systematic uncertainty $(S U)$ incorporates measurement errors:
$S U=\frac{\sqrt{\text { Sum of the squared errors }}}{\text { Number of observations }}$

and where geologic uncertainty $(G U)$ incorporates the clustering of the dataset, which is typically interpreted as the effects of preand post-depositional processes that modify cosmogenic nuclide concentrations:

$G U=$ Standard deviation 

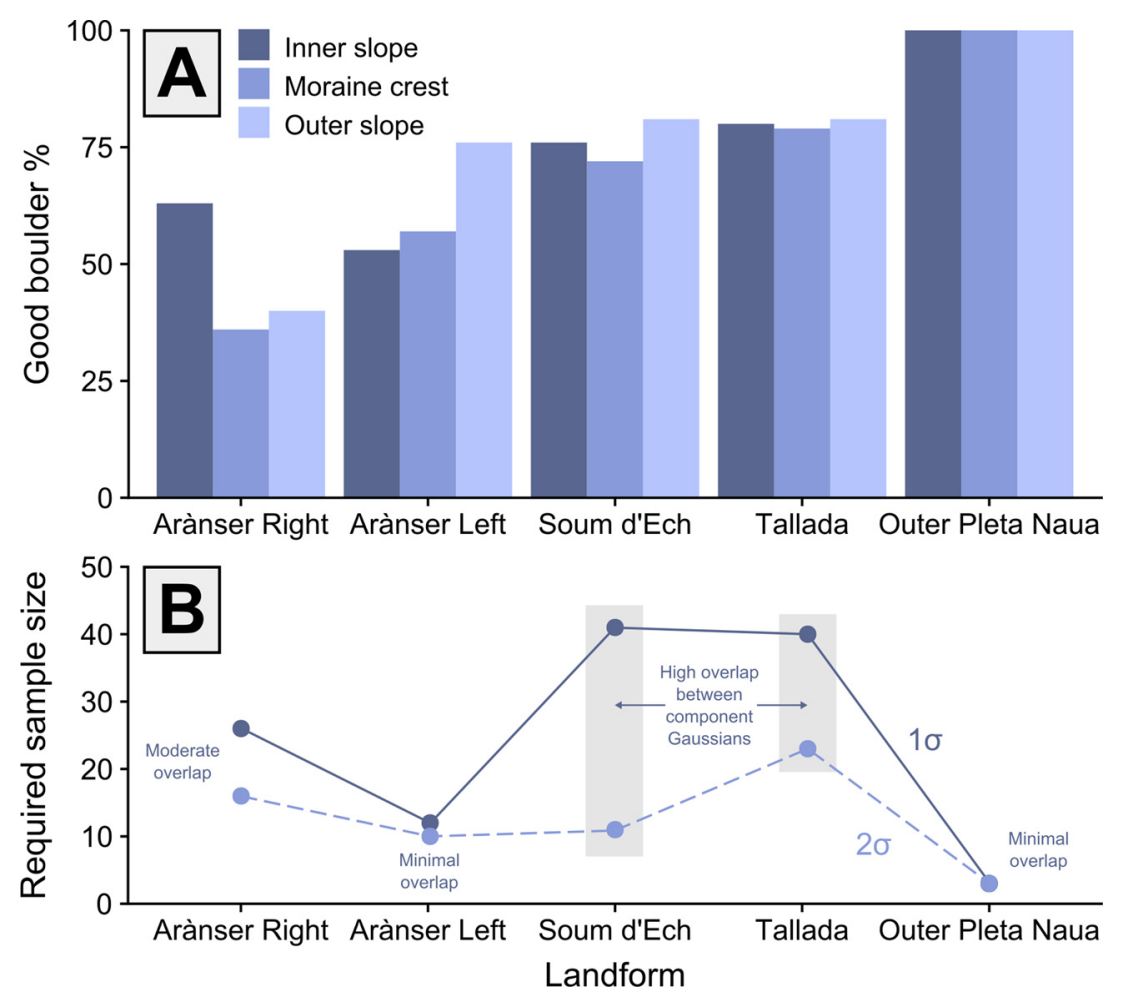

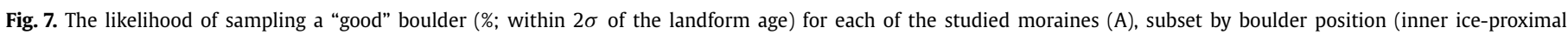

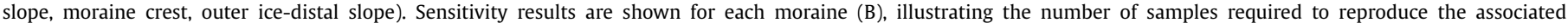
landform age within $1 \sigma$ and $2 \sigma$ thresholds.

In turn, the Outer Pleta Naua moraine was likely deposited at $12.5 \pm 0.4 \mathrm{ka}$. Applying the same analytical approach $(\bar{x} \pm t)$ to the corresponding ${ }^{10} \mathrm{Be}$ ages produces $12.9 \pm 1.0 \mathrm{ka}$, which is statistically indistinguishable. Moreover, these estimates are stratigraphically consistent with independent landform ages in the Val de Molières catchment (Pallàs et al., 2006), with maximum and minimum limiting ages for moraine deposition provided by samples from the Molières (MUL01 $=14.9 \pm 2.6 \mathrm{ka}$, MUL03 $=14.9 \pm$ $1.9 \mathrm{ka}$ ) and Inner Pleta Naua moraines respectively (Fig. 3B; IPN01 $=6.3 \pm 0.9$ ka; Pallàs et al., 2006).

Finally, the Tallada cirque moraine returned a landform age of $3.2 \pm 0.7 \mathrm{ka}$. While this SH-derived estimate cannot be independently verified, the limited weathering of the moraine boulders (SH $R \geq 60$ ), in combination with the topographic setting of the Tallada cirque, appears consistent with a late-Holocene origin.

\subsection{Temporal distribution}

Estimated landform ages are generally consistent with independent TCN ages $(n=19)$ but the age distribution of SH-calibrated exposure ages varies significantly between the sampled moraines (Fig. 5). For the Arànser and Soum d'Ech moraines, the distribution of SH-calibrated exposure ages is strongly negatively skewed (Table 2), in line with exhumation models (Applegate et al., 2012), while Tallada is normally distributed with a slight positive skew (Shapiro-Wilk test, $W=0.98, p=0.56$ ); a trend which may reflect prior exposure or reworking of glacial material (Applegate et al., 2010).

In light of these trends, the proportion of "good" and "bad" boulders, as defined by the $2 \sigma$ age boundaries of the corresponding landform age, varies between the sampled moraines. The proportion of "good" boulders is highest on the Outer Pleta Naua moraine (100\%) and lowest on the Arànser left (56\%) and Arànser right moraines (49\%). For moraines corresponding to the LGM, most "bad" boulders are younger than the assumed age of deglaciation (Table 2), while the Holocene Tallada moraine contains a small but significant component of boulders which are older than the assumed age of deglaciation (14\%). Logistic analysis indicates that boulder characteristics (e.g. boulder height) did not have a consistent statistically significant effect on the distribution of "good" and "bad" boulders across the sampled moraines (see Supplementary Information).

\subsection{Spatial distribution}

Summary statistics for spatial analysis are presented in Table 3. This approach reveals marked inter-landform variation, with statistically significant spatial clustering absent from the Tallada, Outer Pleta Naua and Arànser right moraines (simulated $p>0.05$ ). In turn, the spatial distribution of "good" and "bad" boulders for these moraines is effectively random.

One exception to this rule is the Arànser left moraine where statistically significant clustering is evident (simulated $p<0.05$ ) and where clusters identified using local Moran's $I$ have plausible geomorphological explanations (Fig. 6A). Clusters of "young" boulders occur:

(i) at the moraine terminus,

(ii) where the moraine crest has been cross-cut and incised by a minor stream and,

(iii) where boulders have accumulated at the base of the moraine slope.

Additional clusters are also evident on the ice-proximal slope (Fig. 6A). Clusters (i) and (ii) are likely fluvial in origin, with the former explained by incision of the terminal deposits, which may have led to degradation of the lateral flanks and exhumation of moraine boulders. This pattern of post-depositional degradation matches the spatial clustering of ${ }^{36} \mathrm{Cl}$ ages on a comparable LGM moraine deposited in the nearby Duran valley (see Fig. 11 in Pala- 
cios et al., 2015). The second cluster may be partially explained by meltwater erosion, given the proximity of the incised area to the former terminus of the Setut glacier (Fig. 2A). The origins of the remaining "young" clusters are less clear, but these ultimately reflect instability of the ice-proximal slope, although it is not yet clear whether this was driven by autogenic moraine stabilisation or external factors (e.g. subsequent glacial advance, fluvial erosion). Clusters of "good" boulders were also identified on the Arànser left moraine but these are distributed across moraine crests and ice-proximal and -distal slopes and follow no clear spatial pattern. Finally, local Moran's I identified both "young" and "good" clusters on the outer Soum d'Ech moraine (Fig. 6B) but there is no clear geomorphological evidence which explains their distribution.

The proportion of "good" boulders varies markedly between the studied moraines, but this overall trend is relatively consistent across boulder groups (C, IS, OS) at the intra-landform scale (Fig. 7A). While there are clear differences between boulder groups at the Arànser left and right moraines, there are no consistent trends at the inter-landform scale and no single boulder group performs optimally across all landforms.

\subsection{Sensitivity results}

Based on the sensitivity analysis described in Section 2.6, there are clear differences in the number of $\mathrm{SH}$ samples required to reproduce the landform ages obtained from the full datasets $(n=$ 60 - 275; Fig. 7B). The Outer Pleta Naua landform age requires only three samples at both $1 \sigma$ and $2 \sigma$. Landform ages for both the Arànser left and right moraines can be reproduced with relatively few samples at both $1 \sigma(n \leq 26)$ and $2 \sigma(n \leq 16)$, while both the Soum d'Ech and Tallada moraines require $\geq 40$ samples to reproduce the landform age at $1 \sigma$.

These trends are largely explained by the degree of overlap between component Gaussian distributions (see Fig. 5). Both the Tallada (Fig. 5A) and Soum d'Ech moraines (Fig. 5E) feature lower probability component Gaussians, centred on $4.7 \pm 0.9$ ka and 24.4 \pm 1.7 ka respectively, which overlap with the highest probability component Gaussian. In contrast, there is minimal overlap between component Gaussians for the Arànser left moraine (Fig. 5C), despite the high degree of dataset skew and the large number of "bad" boulders (44\%). The Arànser right moraine is intermediate in character (Fig. 5D), with clear unidirectional skew but a greater degree of overlap between the highest probability Gaussian (22.3 \pm $0.9 \mathrm{ka}$ ) and younger lower probability component Gaussians (17.6 $\pm 2.9 \mathrm{ka} ; 20.9 \pm 0.9 \mathrm{ka}$ ). This distribution explains the larger number of samples required at both $1 \sigma$ and $2 \sigma$ relative to the Arànser left moraine. Ultimately, as the degree of overlap between component Gaussians increases, more samples are required to isolate the highest probability component Gaussian and eliminate PDE skew. Despite this, all landform ages could be reproduced with relatively few samples at both $1 \sigma(\mathrm{n} \leq 40)$ and $2 \sigma(\mathrm{n} \leq 26)$. While these values exceed typical sample size recommendations for TCN dating (Putkonen and Swanson, 2003), they are based upon strict thresholds ( $\geq 95 \%$ of simulated landform ages within $1 \sigma$ or $2 \sigma$ of the full dataset landform age) and should be utilised by researchers when pre-screening a larger population of boulders prior to targeted TCN sampling.

\section{Discussion}

Efforts to minimise sampling bias of moraine TCN datasets may significantly improve the utility of moraine chronologies in determining glacial history and the climatic drivers of glacial cycles. However, while careful geomorphological assessment of individual boulders is necessary to isolate those influenced by pre- or post-depositional processes, many criteria for TCN sample selection have not been tested quantitatively. Of these, boulder location is traditionally thought to be critical, as moraine crest boulders are prioritised due to perceived stability (e.g. Gosse et al., 1995; Hallet and Putkonen, 1994), while those deposited on ice-proximal or -distal slopes are typically rejected. This study is the first to quantitatively assess this approach.

Based on ${ }^{10} \mathrm{Be}(n=10)$ and Schmidt hammer sampling ( $n=$ 635) of ice-marginal moraines in the Pyrenees, it is clear that the spatial distribution of SH-calibrated exposure ages is both complex and site-specific. For many moraines, the distribution of "good" and "bad" boulders is effectively random ( $p>0.05)$, as assessed using global Moran's I (Table 3), while in others, clusters of "good" and "bad" boulders have clear geomorphological explanations. More fundamentally, the likelihood of selecting a "good" boulder is comparable for moraine crests, ice-proximal and -distal slopes (Fig. 7A). Although statistically significant spatial clustering is evident for the Arànser left and Soum d'Ech moraines $(p<0.05$; Fig. 6), the distribution of "good" boulder clusters is complex, with clusters distributed across moraine crests and moraine slopes.

While there are no consistent spatial patterns at the interlandform scale, the temporal distribution of SH-calibrated exposure ages varies markedly between the studied landforms, with a number of important observations. First, moraine sedimentology appears to place a key control on post-depositional stability (Zreda et al., 1994; Putkonen and O'Neal, 2006), as age distributions for matrix-rich moraines (e.g. Arànser, Soum d'Ech) are strongly negatively skewed (Fig. 6), with many boulders younger than the assigned age of the landform. The frequency of "young" boulders for these moraines (Table 2) likely reflects the influence of diffusive slope processes (Applegate et al., 2010), as the transfer of sediment to the base of moraine slopes drives exhumation of entrained boulders (Porter and Swanson, 2008) and erosion of moraine crests (Schaller et al., 2009) and leads to increasingly subdued moraine topography (Putkonen and O'Neal, 2006). The clearest signal of moraine degradation is evident at the Arànser left $(I Q R=7.9 \mathrm{ka}$; Skew $=-1.02)$ and Arànser right moraines $(I Q R=6.9 \mathrm{ka}$; Skew = -1.13) and this trend may be partially explained by forest growth and boulder toppling (Ivy-Ochs et al., 2007), as well as the effects of fluvial incision (Fig. 6), while historic land use may also play a role (Pallàs et al., 2010).

In contrast, the boulder-rich, matrix-poor Outer Pleta Naua moraine stabilised rapidly after glacial retreat, as evidenced by the distribution and clustering of both its SH-calibrated exposure ages $(\mathrm{IQR}=0.6 \mathrm{ka}$; Shapiro Wilk $W=0.96, p=0.07)$ and the corresponding ${ }^{10}$ Be dataset (Pallàs et al., 2006). The sedimentology of the Outer Pleta Naua moraine is likely a function of catchment size and glacier area, and the short transport distance from the bedrock source area (Fig. $3 ; \leq 300 \mathrm{~m}$ ). In the absence of a supporting sediment matrix, boulder-rich moraines stabilise quickly and appear less susceptible to subsequent erosion (Ivy-Ochs et al., 2007; Pallàs et al., 2010). Finally, for moraines deposited by niche cirque glaciers, reworking of glacial, periglacial or rockfall material appears more significant than post-depositional modification, in line with previous studies (Heyman et al., 2011). In these environments, the age of the oldest boulder may overestimate the "true" age of the moraine (Putkonen and Swanson, 2003; Briner et al., 2005).

\subsection{Implications for TCN sampling of moraines}

The results described above have implications for future sampling approaches. First, while "good" boulders are not more likely on moraine crests, we find there is no clear penalty to moraine crest sampling, as initial differences between moraine crests and ice-proximal and -distal slopes appear to be masked by continued 
moraine degradation. Thus, in the absence of detailed geomorphological assessments of individual landforms, restricting sampling to moraine crests is a viable strategy to minimise the likelihood of boulder instability, assuming there are sufficient numbers of boulders to select from. This finding is unlikely to hold true for recently deposited ( $<1 \mathrm{ka}$ ) unconsolidated landforms (Putkonen and O'Neal, 2006), whose over-steepened ice-proximal slopes have yet to stabilise (Briner et al., 2005; Dortch et al., 2010).

Second, our results show that sampling boulders on iceproximal and -distal slopes can be as effective as sampling moraine crests (Fig. 7A). While boulder density is typically highest at moraine crests (Putkonen et al., 2008), there is no guarantee that these boulders are the best options for TCN dating. Moreover, if sample selection criteria are rigorously applied, the number of suitable boulders available for dating could fall below a critical level. Without robust statistical identification of outliers, this could lead to unclear results given the ubiquity of post-depositional modification of moraines (Zech et al., 2005; Heyman et al., 2011). One strategy which is rarely utilised is to select boulders for TCN dating from ice-proximal and -distal slopes, but evidence from the studied moraines indicates that this is a viable strategy, as the proportion of "good" boulders is comparable to moraine crests (Fig. 7A). For many moraines, the spatial distribution of "good" boulders is random, while statistically significant clusters of "good" boulders are distributed across moraine crests and moraine slopes (Fig. 6). These observations indicate that redefining selection criteria to include the entire population of moraine boulders would have no clear negative effect and could prove beneficial for moraines where ideal boulders are rare or are distributed away from moraine crests.

Third, our data indicate that landform characteristics have a clear impact on the temporal distribution of SH-calibrated exposure ages (Fig. 5; Putkonen and O'Neal, 2006; Ivy-Ochs et al., 2007; Pallàs et al., 2010). Within this context, we suggest that landform stability should be prioritised, as differences between landforms appear far greater than differences between boulder groups on an individual landform (C vs. IS vs. OS). Differences are evident as a function of moraine sedimentology (Zreda et al., 1994), with rapid stabilisation of matrix-poor, boulder-rich moraines (e.g. Outer Pleta Naua; Pallàs et al., 2006, 2010; Ivy-Ochs et al., 2007) but prolonged degradation of unconsolidated landforms (e.g. Arànser; Putkonen and O'Neal, 2006; Dortch et al., 2010). Although moraine sedimentology has explanatory power for the studied moraines, the observed trends are unlikely to hold true in all settings due to climatic and topographic controls on moraine stability (Barr and Lovell, 2014). Moreover, restricting sampling to matrix-poor landforms could have unintended adverse effects, as moraines may incorporate supraglacial rock avalanche debris and may primarily preserve a non-climatic signal. Alternatively, sampling unconsolidated landforms does not guarantee poor clustering (e.g. $\chi^{2}>1$ ), particularly in regions where moraine denudation is limited by climate (Zech et al., 2005; Morgan et al., 2011; Balter et al., 2020) or where topographic factors promote moraine stability (Barr and Lovell, 2014). Finally, restricting sampling to landforms with specific characteristics is often not viable, as key glacial chronological markers may be represented by only a small number of landforms.

Within this context, we suggest that landform selection is critical, and care should be taken to select methods which are appropriate for its assumed age and stability and to collect a sufficient number of samples to enable robust outlier identification (Putkonen and Swanson, 2003). However, it is often challenging to assess landform stability based on geomorphological evidence alone. Our approach, in light of strong regional evidence for an inverse correlation between SH $R$-values and exposure ages for granitic surfaces (Tomkins et al., 2018a, 2018b), indicates that preliminary SH sampling could be a useful method to assess landform stability, to identify boulders affected by post-depositional processes, and to prioritise individual boulders for analysis based on $R$-value clustering (Tylmann et al., 2018).

Based on the sensitivity approach described in Section 2.6, the number of $\mathrm{SH}$ samples required scales with the complexity of the underlying distribution (Fig. 7B), from those which are approximately normal to those which feature overlapping component Gaussian distributions (Fig. 5) or multi-directional skew (i.e. preand post-depositional skew). However, given that it is not possible to ascertain the underlying distribution a priori, a relatively large sample size is ultimately required. For most landforms, sampling a minimum of $\sim 30$ boulders would be a reasonable approach to estimate a depositional age within $2 \sigma$ ( $n \geq 23$ ), but more would be required $(n \geq 40$ ) to improve precision to $1 \sigma$ for complex datasets or if Schmidt hammer $R$-values were being used as a basis for cosmogenic nuclide sample selection (Tylmann et al., 2018). Collecting a minimum of 30 - 40 samples is necessary to ensure a full understanding of the underlying age distribution, even for complex datasets. Based on this preliminary sampling, statistical approaches could be used to isolate component Gaussian distributions (Dortch et al., 2013, 2021) and to identify individual boulders which are consistent with the age of the landform and to reject those which are "young" or "old" (Heyman et al., 2011).

Finally, it is important to note that the effectiveness of this approach may vary as a function of lithology and climate (McCarroll, 1989), while the underlying measurements are sensitive to factors which have only a minor effect on cosmogenic nuclide concentrations (e.g. surface discontinuities, Williams and Robinson, 1983; lichen coverage, Matthews and Owen, 2008). However, when these limitations are accounted for, Schmidt hammer $R$-values can be used as a proxy for surface exposure age (Fig. 4). Given the ubiquity of geologic scatter (e.g. exhumation, erosion, shielding), incorporating time- and cost-efficient preliminary SH sampling as an additional tool for TCN sample selection could ultimately improve the chronological utility of the moraine record and enable a deeper understanding of the climatic drivers of glacial cycles.

\section{Conclusions}

Based on ${ }^{10} \mathrm{Be}$ and Schmidt hammer sampling of ice-marginal moraines in the Pyrenees, this study provided the first quantitative analysis of the relative utility of moraine crest and moraine slope sampling for terrestrial cosmogenic nuclide dating. Using spatial analysis of SH-calibrated exposure ages, we show that there is no clear penalty to moraine slope sampling. However, contrary to current sampling approaches, which typically prioritise moraine crest boulders due to perceived stability, we show that the proportion of "good" boulders is comparable between moraine crests and ice-proximal and -distal slopes, while for many moraines, the spatial distribution of "good" boulders is effectively random. Crucially, however, differences between landforms appear more significant than differences at the intra-landform scale; a result which indicates that the stability of the landform can have a far greater impact on the distribution of boulder exposure ages than the characteristics and depositional context of individual boulders. In this study, moraine sedimentology likely accounts for the observed differences between landforms, with rapid stabilisation of matrix-poor, boulder-rich moraines and prolonged degradation for unconsolidated landforms. Although these trends are unlikely to be universally applicable given climatic and topographic controls on moraine stability, our data indicate that preliminary SH sampling is a valuable tool to assess landform stability and to prioritise individual boulders for further analysis. 


\section{CRediT authorship contribution statement}

Matt D. Tomkins: Conceptualization, Formal analysis, Funding acquisition, Investigation, Methodology, Software, Visualization, Writing - original draft, Writing - review \& editing. Jason M. Dortch: Conceptualization, Formal analysis, Methodology, Software, Supervision, Visualization, Writing - review \& editing. Philip D. Hughes: Conceptualization, Methodology, Supervision, Writing review \& editing. Jonny J. Huck: Formal analysis, Methodology, Software, Supervision, Writing - review \& editing. Raimon Pallàs: Conceptualization, Funding acquisition, Investigation, Methodology, Writing - original draft. Ángel Rodés: Conceptualization, Funding acquisition, Investigation, Methodology. James L. Allard: Investigation, Writing - review \& editing. Andrew G. Stimson: Investigation, Writing - review \& editing. Didier Bourlès: Funding acquisition, Investigation, Writing - review \& editing. Vincent Rinterknecht: Funding acquisition, Investigation, Writing - review \& editing. Vincent Jomelli: Funding acquisition, Investigation, Writing - review \& editing. Laura Rodríguez-Rodríguez: Funding acquisition, Investigation, Writing - review \& editing. Ramon Copons: Funding acquisition, Investigation, Writing - review \& editing. Iestyn D. Barr: Conceptualization, Writing - review \& editing. Christopher M. Darvill: Conceptualization, Writing - review \& editing. Thomas Bishop: Methodology, Software, Writing - review \& editing.

\section{Declaration of competing interest}

The authors declare that they have no known competing financial interests or personal relationships that could have appeared to influence the work reported in this paper.

\section{Acknowledgements}

MT was funded by a University of Manchester President's Doctoral Scholar Award. The fieldwork for this paper was supported by a British Society for Geomorphology Postgraduate Research grant awarded to MT. ${ }^{10} \mathrm{Be}$ analysis was performed at the ASTER AMS national facility (CEREGE), which is supported by the CNRS/INSU, by the ANR, through the "projets thématiques d'excellence" programme for the "Equipements d'excellence" ASTER-CEREGE action, and by the Institut de Recherche pour le Développement (IRD). MT, JD, PH and RP designed the project, with refinements from IB and CD. MT, JA and AS conducted Schmidt hammer sampling. ${ }^{10} \mathrm{Be}$ sampling and analysis was undertaken by RP, AR, DB, VR, VJ, LRR and RC. MT and JH conducted spatial analysis. MT, JH and TB improved error propagation. All authors contributed to the manuscript. We would like to thank Professor W. Amidon for his constructive review. We thank Dr. G. Evatt and Dr. A. Smedley at the University of Manchester for their comments, D. Tomkins and Dr. B. van Bodegraven for fieldwork support, and the contributors to the open-source libraries PySAL and GeoPandas.

\section{Appendix A. Supplementary material}

Supplementary material related to this article can be found online at https://doi.org/10.1016/j.epsl.2021.117092.

\section{References}

Applegate, P.J., Urban, N.M., Keller, K., Lowell, T.V., Laabs, B.J.C., Kelly, M.A., Alley, R.B., 2012. Improved moraine age interpretations through explicit matching of geomorphic process models to cosmogenic nuclide measurements from single landforms. Quat. Res. 77, 293-304. https://doi.org/10.1016/j.yqres.2011.12.002.

Applegate, P.J., Urban, N.M., Laabs, B.J.C., Keller, K., Alley, R.B., 2010. Modeling the statistical distributions of cosmogenic exposure dates from moraines. Geosci. Model Dev. 3, 293-307. https://doi.org/10.5194/gmd-3-293-2010.
Balter, A., Bromley, G., Balco, G., Thomas, H., Jackson, M.S., 2020. A 14.5-million-year record of East Antarctic Ice Sheet fluctuations from the central Transantarctic Mountains, constrained with cosmogenic ${ }^{3} \mathrm{He},{ }^{10} \mathrm{Be},{ }^{21} \mathrm{Ne}$, and ${ }^{26} \mathrm{Al}$. Cryosphere Discuss., 1-41. https://doi.org/10.5194/tc-2020-57.

Barr, I.D., Lovell, H., 2014. A review of topographic controls on moraine distribution. Geomorphology 226, 44-64. https://doi.org/10.1016/j.geomorph.2014.07.030.

Boggs, Paul T., Rogers, J.E., 1990. Orthogonal distance regression. In: Statistical Analysis of Measurement Error Models and Applications: Proceedings of the AMSIMS-SIAM Joint Summer Research Conference. June 10-16, 1989. In: Presented at the Contemporary Mathematics, p. 186.

Borchers, B., Marrero, S., Balco, G., Caffee, M., Goehring, B., Lifton, N., Nishiizumi, K., Phillips, F., Schaefer, J., Stone, J., 2016. Geological calibration of spallation production rates in the CRONUS-Earth project. Quat. Geochronol. 31, 188-198. https://doi.org/10.1016/j.quageo.2015.01.009.

Briner, J.P., Kaufman, D.S., Manley, W.F., Finkel, R.C., Caffee, M.W., 2005. Cosmogenic exposure dating of late Pleistocene moraine stabilization in Alaska. GSA Bull. 117, 1108-1120. https://doi.org/10.1130/B25649.1.

Calvet, M., Delmas, M., Gunnell, Y., Braucher, R., Bourlès, D., 2011. Recent advances in research on quaternary glaciations in the Pyrenees. In: Ehlers, J., Gibbard, P.L., Hughes, P.D. (Eds.), Developments in Quaternary Sciences, Quaternary Glaciations - Extent and Chronology. Elsevier, pp. 127-139. Chapter 11.

Chevalier, M.-L., Replumaz, A., 2019. Deciphering old moraine age distributions in SE Tibet showing bimodal climatic signal for glaciations: marine isotope stages 2 and 6. Earth Planet. Sci. Lett. 507, 105-118. https://doi.org/10.1016/j.epsl.2018. 11.033.

Darmody, R.G., Thorn, C.E., Allen, C.E., 2005. Chemical weathering and boulder mantles, Kärkevagge, Swedish Lapland. Geomorphology 67, 159-170. https:// doi.org/10.1016/j.geomorph.2004.07.011. Weathering and landscape evolution.

Darvill, C.M., Bentley, M.J., Stokes, C.R., 2015. Geomorphology and weathering characteristics of erratic boulder trains on Tierra del Fuego, southernmost South America: implications for dating of glacial deposits. Geomorphology 228, 382-397. https://doi.org/10.1016/j.geomorph.2014.09.017.

Dortch, J.M., Owen, L.A., Caffee, M.W., Li, D., Lowell, T.V., 2010. Beryllium-10 surface exposure dating of glacial successions in the Central Alaska Range. J. Quat. Sci. 25, 1259-1269. https://doi.org/10.1002/jqs.1406.

Dortch, J.M., Owen, L.A., Caffee, M.W., 2013. Timing and climatic drivers for glaciation across semi-arid western Himalayan-Tibetan orogen. Quat. Sci. Rev. 78, 188-208. https://doi.org/10.1016/j.quascirev.2013.07.025.

Dortch, J.M., Tomkins, M.D., Saha, S., Murari, M.K., Schoenbohm, L.M., Curl, D., 2021. Probabilistic Cosmogenic Age Analysis Tool (P-CAAT), a tool for the ages. Manuscript in preparation.

Ehlmann, B.L., Viles, H.A., Bourke, M.C., 2008. Quantitative morphologic analysis of boulder shape and surface texture to infer environmental history: a case study of rock breakdown at the Ephrata Fan, Channeled Scabland, Washington. J. Geophys. Res., Earth Surf. 113. https://doi.org/10.1029/2007JF000872.

Gosse, J.C., Evenson, E.B., Klein, J., Lawn, B., Middleton, R., 1995. Precise cosmogenic ${ }^{10} \mathrm{Be}$ measurements in western North America: support for a global Younger Dryas cooling event. Geology 23, 877-880. https://doi.org/10.1130/ 0091-7613(1995)023<0877:PCBMIW>2.3.CO;2.

Hallet, B., Putkonen, J., 1994. Surface dating of dynamic landforms: young boulders on aging moraines. Science 265, 937-940. https://doi.org/10.1126/science.265. 5174.937.

Heyman, J., Applegate, P.J., Blomdin, R., Gribenski, N., Harbor, J.M., Stroeven, A.P., 2016. Boulder height - exposure age relationships from a global glacial ${ }^{10} \mathrm{Be}$ compilation. Quat. Geochronol. 34, 1-11. https://doi.org/10.1016/j.quageo.2016. 03.002 .

Heyman, J., Stroeven, A.P., Harbor, J.M., Caffee, M.W., 2011. Too young or too old: evaluating cosmogenic exposure dating based on an analysis of compiled boulder exposure ages. Earth Planet. Sci. Lett. 302, 71-80. https://doi.org/10.1016/j. epsl.2010.11.040.

Ivy-Ochs, S., Kerschner, H., Schlüchter, C., 2007. Cosmogenic nuclides and the dating of lateglacial and early Holocene glacier variations: the Alpine perspective. Quat. Int. 164-165, 53-63. https://doi.org/10.1016/j.quaint.2006.12.008. From the Swiss Alps to the Crimean Mountains - Alpine Quaternary stratigraphy in a European context.

Lal, D., 1991. Cosmic ray labeling of erosion surfaces: in situ nuclide production rates and erosion models. Earth Planet. Sci. Lett. 104, 424-439. https://doi.org/ 10.1016/0012-821X(91)90220-C.

Marrero, S.M., Hein, A.S., Naylor, M., Attal, M., Shanks, R., Winter, K., Woodward, J., Dunning, S., Westoby, M., Sugden, D., 2018. Controls on subaerial erosion rates in Antarctica. Earth Planet. Sci. Lett. 501, 56-66. https://doi.org/10.1016/j.epsl. 2018.08.018.

Marrero, S.M., Phillips, F.M., Borchers, B., Lifton, N., Aumer, R., Balco, G., 2016. Cosmogenic nuclide systematics and the CRONUScalc program. Quat. Geochronol. 31, 160-187. https://doi.org/10.1016/j.quageo.2015.09.005.

Matthews, J.A., Owen, G., 2008. Endolithic lichens, rapid biological weathering and Schmidt hammer R-values on recently exposed rock surfaces: Storbreen Glacier Foreland, Jotunheimen, Norway. Geogr. Ann., Ser. A, Phys. Geogr. 90, 287-297. https://doi.org/10.1111/j.1468-0459.2008.00346.x. 
McCarroll, D., 1989. Potential and limitations of the Schmidt hammer for relativeage dating: field tests on neoglacial moraines, Jotunheimen, Southern Norway. Arct. Alp. Res. 21, 268-275. https://doi.org/10.2307/1551565.

Morgan, D.J., Putkonen, J., Balco, G., Stone, J., 2011. Degradation of glacial deposits quantified with cosmogenic nuclides, Quartermain Mountains, Antarctica. Earth Surf. Process. Landf. 36, 217-228. https://doi.org/10.1002/esp.2039.

Niedzielski, T., Migoń, P., Placek, A., 2009. A minimum sample size required from Schmidt hammer measurements. Earth Surf. Process. Landf. 34, 1713-1725. https://doi.org/10.1002/esp.1851.

Palacios, D., Gómez-Ortiz, A., Andrés, N., Vázquez-Selem, L., Salvador-Franch, F., Oliva, M., 2015. Maximum extent of Late Pleistocene glaciers and last deglaciation of La Cerdanya mountains, Southeastern Pyrenees. Geomorphology 231, 116-129. https://doi.org/10.1016/j.geomorph.2014.10.037.

Pallàs, R., Rodés, Á., Braucher, R., Bourlès, D., Delmas, M., Calvet, M., Gunnell, Y., 2010. Small, isolated glacial catchments as priority targets for cosmogenic surface exposure dating of Pleistocene climate fluctuations, southeastern Pyrenees. Geology 38, 891-894. https://doi.org/10.1130/G31164.1.

Pallàs, R., Rodés, Á., Braucher, R., Carcaillet, J., Ortuño, M., Bordonau, J., Bourlès, D., Vilaplana, J.M., Masana, E., Santanach, P., 2006. Late Pleistocene and Holocene glaciation in the Pyrenees: a critical review and new evidence from ${ }^{10} \mathrm{Be}$ exposure ages, South-central Pyrenees. Quat. Sci. Rev. 25, 2937-2963. https:// doi.org/10.1016/j.quascirev.2006.04.004.

Portenga, E.W., Bierman, P.R., 2011. Understanding Earth's eroding surface with ${ }^{10} \mathrm{Be}$. GSAT 21, 4-10. https://doi.org/10.1130/G111A.1.

Porter, S.C., Swanson, T.W., 2008. ${ }^{36} \mathrm{Cl}$ dating of the classic Pleistocene glacial record in the northeastern Cascade Range, Washington. Am. J. Sci. 308, 130-166. https://doi.org/10.2475/02.2008.02.

Putkonen, J., Connolly, J., Orloff, T., 2008. Landscape evolution degrades the geologic signature of past glaciations. Geomorphology 97, 208-217. https://doi.org/ 10.1016/j.geomorph.2007.02.043. Glacial Landscape Evolution - Implications for Glacial Processes, Patterns and Reconstructions.

Putkonen, J., O'Neal, M., 2006. Degradation of unconsolidated quaternary landforms in the western North America. Geomorphology 75, 408-419. https://doi.org/10. 1016/j.geomorph.2005.07.024. Quaternary landscape change and modern process in western North America.

Putkonen, J., Swanson, T., 2003. Accuracy of cosmogenic ages for moraines. Quat. Res. 59, 255-261. https://doi.org/10.1016/S0033-5894(03)00006-1.

Reille, M., Andrieu, V., 1995. The late Pleistocene and Holocene in the Lourdes Basin, Western Pyrénées, France: new pollen analytical and chronological data. Veg. Hist. Archaeobot. 4, 1-21. https://doi.org/10.1007/BF00198611.

Reimer, P.J., Bard, E., Bayliss, A., Beck, J.W., Blackwell, P.G., Ramsey, C.B., Buck, C.E., Cheng, H., Edwards, R.L., Friedrich, M., Grootes, P.M., Guilderson, T.P., Haflidason, H., Hajdas, I., Hatté, C., Heaton, T.J., Hoffmann, D.L., Hogg, A.G., Hughen, K.A., Kaiser, K.F., Kromer, B., Manning, S.W., Niu, M., Reimer, R.W., Richards, D.A., Scott, E.M., Southon, J.R., Staff, R.A., Turney, C.S.M., van der Plicht, J., 2013. IntCal13 and Marine13 radiocarbon age calibration curves 0-50,000 years cal BP. Radiocarbon 55, 1869-1887. https://doi.org/10.2458/azu_js_rc.55.16947.
Riebe, C.S., Kirchner, J.W., Finkel, R.C., 2004. Erosional and climatic effects on longterm chemical weathering rates in granitic landscapes spanning diverse climate regimes. Earth Planet. Sci. Lett. 224, 547-562. https://doi.org/10.1016/j. epsl.2004.05.019.

Rodés, Á., 2008. La última deglaciación en los pirineos: de superficies de exposición mediante ${ }^{10} \mathrm{Be}$, y modelado numérico de paleoglaciares. Universitat de Barcelona. http://purl.org/dc/dcmitype/Text.

Schaller, M., Ehlers, T.A., Blum, J.D., Kallenberg, M.A., 2009. Quantifying glacial moraine age, denudation, and soil mixing with cosmogenic nuclide depth profiles. J. Geophys. Res., Earth Surf. 114. https://doi.org/10.1029/2007JF000921.

Stone, J.O., 2000. Air pressure and cosmogenic isotope production. J. Geophys. Res., Solid Earth 105, 23753-23759. https://doi.org/10.1029/2000JB900181.

Stübner, K., Grin, E., Hidy, A.J., Schaller, M., Gold, R.D., Ratschbacher, L., Ehlers, T., 2017. Middle and Late Pleistocene glaciations in the southwestern Pamir and their effects on topography. Earth Planet. Sci. Lett. 466, 181-194. https://doi. org/10.1016/j.epsl.2017.03.012.

Sumner, P., Nel, W., 2002. The effect of rock moisture on Schmidt hammer rebound: tests on rock samples from Marion Island and South Africa. Earth Surf. Process. Landf. 27, 1137-1142. https://doi.org/10.1002/esp.402.

Tomkins, M.D., Huck, J.J., Dortch, J.M., Hughes, P.D., Kirkbride, M.P., Barr, I.D., 2018a. Schmidt Hammer exposure dating (SHED): calibration procedures, new exposure age data and an online calculator. Quat. Geochronol. 44, 55-62. https:// doi.org/10.1016/j.quageo.2017.12.003.

Tomkins, M.D., Dortch, J.M., Hughes, P.D., Huck, J.J., Stimson, A.G., Delmas, M., Calvet, M., Pallàs, R., 2018b. Rapid age assessment of glacial landforms in the Pyrenees using Schmidt hammer exposure dating (SHED). Quat. Res. 90, 26-37. https:// doi.org/10.1017/qua.2018.12.

Tylmann, K., Woźniak, P.P., Rinterknecht, V.R., 2018. Erratics selection for cosmogenic nuclide exposure dating - an optimization approach. Baltica 31, 100-114. https://doi.org/10.5200/baltica.2018.31.10.

Williams, R.B.G., Robinson, D.A., 1983. The effect of surface texture on the determination of the surface hardness of rock using the Schmidt hammer. Earth Surf. Process. Landf. 8, 289-292. https://doi.org/10.1002/esp.3290080311.

Zech, R., Glaser, B., Sosin, P., Kubik, P.W., Zech, W., 2005. Evidence for long-lasting landform surface instability on hummocky moraines in the Pamir Mountains (Tajikistan) from ${ }^{10} \mathrm{Be}$ surface exposure dating. Earth Planet. Sci. Lett. 237, 453-461. https://doi.org/10.1016/j.epsl.2005.06.031.

Zreda, M.G., Phillips, F.M., 1995. Insights into Alpine moraine development from cosmogenic ${ }^{36} \mathrm{Cl}$ buildup dating. Geomorphology 14, 149-156. https://doi.org/10. 1016/0169-555X(95)00055-9. Glacial Geomorphology: Process and Form Development.

Zreda, M.G., Phillips, F.M., Elmore, D., 1994. Cosmogenic ${ }^{36} \mathrm{Cl}$ accumulation in unstable landforms: 2. Simulations and measurements on eroding moraines. Water Resour. Res. 30, 3127-3136. https://doi.org/10.1029/94WR00760. 